\title{
Missing OH reactivity in the global marine boundary layer
}

\author{
Alexander B. Thames ${ }^{1}$, William H. Brune ${ }^{1}$, David O. Miller ${ }^{1}$, Hannah M. Allen ${ }^{2}$, Eric C. Apel ${ }^{3}$, Donald R. Blake ${ }^{4}$, \\ T. Paul Bui ${ }^{5}$, Roisin Commane ${ }^{6}$, John D. Crounse ${ }^{7}$, Bruce C. Daube ${ }^{8}$, Glenn S. Diskin ${ }^{9}$, Joshua P. DiGangi ${ }^{9}$, \\ James W. Elkins ${ }^{10}$, Samuel R. Hall ${ }^{3}$, Thomas F. Hanisco ${ }^{11}$, Reem A. Hannun ${ }^{11,12}$, Eric Hintsa ${ }^{10,13}$, \\ Rebecca S. Hornbrook ${ }^{3}$, Michelle J. Kim ${ }^{7}$, Kathryn McKain $^{10,13}$, Fred L. Moore ${ }^{10,13}$, Julie M. Nicely ${ }^{11,14}$, \\ Jeffrey Peischl ${ }^{10,15}$, Thomas B. Ryerson ${ }^{15}$, Jason M. St. Clair ${ }^{11,12}$, Colm Sweeney ${ }^{10}$, Alex Teng ${ }^{2}$, \\ Chelsea R. Thompson ${ }^{13,15}$, Kirk Ullmann ${ }^{3}$, Paul O. Wennberg ${ }^{7,16}$, and Glenn M. Wolfe ${ }^{11,12}$ \\ ${ }^{1}$ Department of Meteorology and Atmospheric Science, The Pennsylvania State University, University Park, PA, USA \\ ${ }^{2}$ Division of Chemistry and Chemical Engineering, California Institute of Technology, Pasadena, CA, USA \\ ${ }^{3}$ Atmospheric Chemistry Observations \& Modeling Laboratory, National Center for Atmospheric Research, \\ Boulder, CO, USA \\ ${ }^{4}$ Department of Chemistry, University of California, Irvine, CA, USA \\ ${ }^{5}$ Earth Science Division, NASA Ames Research Center, Moffett Field, CA, USA \\ ${ }^{6}$ Department of Earth and Environmental Sciences, Lamont-Doherty Earth Observatory, \\ Columbia University, Palisades, NY, USA \\ ${ }^{7}$ Division of Geological and Planetary Sciences, California Institute of Technology, Pasadena, CA, USA \\ ${ }^{8}$ Department of Earth and Planetary Sciences, Harvard University, Cambridge, MA, USA \\ ${ }^{9}$ Chemistry and Dynamics Branch, NASA Langley Research Center, Hampton, VA, USA \\ ${ }^{10}$ Global Monitoring Division, NOAA Earth System Research Laboratory, Boulder, CO, USA \\ ${ }^{11}$ Atmospheric Chemistry and Dynamics Laboratory, NASA Goddard Space Flight Center, Greenbelt, MD, USA \\ ${ }^{12}$ Joint Center for Earth Systems Technology, University of Maryland, Baltimore County, Catonsville, MD, USA \\ ${ }^{13}$ Cooperative Institute for Research in Environmental Sciences, University of Colorado, Boulder, CO, USA \\ ${ }^{14}$ Earth System Science Interdisciplinary Center, University of Maryland, College Park, MD, USA \\ ${ }^{15}$ Chemical Sciences Division, NOAA Earth System Research Laboratory, Boulder, CO, USA \\ ${ }^{16}$ Division of Engineering and Applied Science, California Institute of Technology, Pasadena, CA, USA
}

Correspondence: William H. Brune (whb2@psu.edu)

Received: 24 September 2019 - Discussion started: 16 October 2019

Revised: 30 January 2020 - Accepted: 2 March 2020 - Published: 2 April 2020

\begin{abstract}
The hydroxyl radical $(\mathrm{OH})$ reacts with thousands of chemical species in the atmosphere, initiating their removal and the chemical reaction sequences that produce ozone, secondary aerosols, and gas-phase acids. $\mathrm{OH}$ reactivity, which is the inverse of $\mathrm{OH}$ lifetime, influences the $\mathrm{OH}$ abundance and the ability of $\mathrm{OH}$ to cleanse the atmosphere. The NASA Atmospheric Tomography (ATom) campaign used instruments on the NASA DC-8 aircraft to measure $\mathrm{OH}$ reactivity and more than 100 trace chemical species. ATom presented a unique opportunity to test the completeness of the $\mathrm{OH}$ reactivity calculated from the chemical species measurements by comparing it to the measured $\mathrm{OH}$ reactivity over two oceans across four seasons. Although
\end{abstract}

the calculated $\mathrm{OH}$ reactivity was below the limit of detection for the ATom instrument used to measure $\mathrm{OH}$ reactivity throughout much of the free troposphere, the instrument was able to measure the $\mathrm{OH}$ reactivity in and just above the marine boundary layer. The mean measured value of $\mathrm{OH}$ reactivity in the marine boundary layer across all latitudes and all ATom deployments was $1.9 \mathrm{~s}^{-1}$, which is $0.5 \mathrm{~s}^{-1}$ larger than the mean calculated $\mathrm{OH}$ reactivity. The missing $\mathrm{OH}$ reactivity, the difference between the measured and calculated $\mathrm{OH}$ reactivity, varied between 0 and $3.5 \mathrm{~s}^{-1}$, with the highest values over the Northern Hemisphere Pacific Ocean. Correlations of missing $\mathrm{OH}$ reactivity with formaldehyde, dimethyl sulfide, butanal, and sea surface temperature sug- 
gest the presence of unmeasured or unknown volatile organic compounds or oxygenated volatile organic compounds associated with ocean emissions.

\section{Introduction}

The primary fate of the thousands of trace gases emitted into the atmosphere is chemical reaction with the hydroxyl radical $(\mathrm{OH})$. While $\mathrm{OH}$ is produced primarily by the photolysis of ozone, followed by a reaction between excited-state atomic oxygen and water vapor, $\mathrm{OH}$ is lost at the rate determined by the sum of the reaction frequencies with these trace gases. This sum of loss frequencies is called the $\mathrm{OH}$ reactivity and has units of per second $\left(\mathrm{s}^{-1}\right)$. If $\mathrm{OH}$ production remains constant, increases in $\mathrm{OH}$ reactivity will decrease the total atmospheric $\mathrm{OH}$ concentration. Thus, understanding global $\mathrm{OH}$ reactivity is a key to understanding global $\mathrm{OH}$ and the global atmospheric oxidation capacity.

An important example is methane $\left(\mathrm{CH}_{4}\right)$, which is removed from the atmosphere primarily by reaction with $\mathrm{OH}$. Two estimates of the $\mathrm{CH}_{4}$ lifetime due to oxidation by $\mathrm{OH}$ are $9.7 \pm 1.5$ years (Naik et al., 2013) and $11.2 \pm 1.3$ years (Prather et al., 2012). A recent global inverse analysis of GOSAT satellite $\mathrm{CH}_{4}$ column emissions finds a $\mathrm{CH}_{4}$ lifetime of $10.8 \pm 0.4$ years for oxidation by tropospheric $\mathrm{OH}$ (Maasakkers et al., 2019), which is within the uncertainties of the other two estimates. Understanding the $\mathrm{CH}_{4}$ lifetime depends on understanding global spatial and temporal $\mathrm{OH}$ distributions, which are strongly influenced by the spatial and temporal distribution of $\mathrm{OH}$ reactivity.

$\mathrm{OH}$ reactivity is the inverse of the $\mathrm{OH}$ lifetime. It is calculated as a sum of $\mathrm{OH}$ reactant concentrations multiplied by their reaction rate coefficients:

$k_{\mathrm{OH}}=\sum_{i} k_{\left(\mathrm{OH}+\mathrm{X}_{i}\right)}\left[\mathrm{X}_{i}\right]$

where $k_{\left(\mathrm{OH}+\mathrm{X}_{i}\right)}$ represents some species $\mathrm{X}$ 's reaction rate coefficient with $\mathrm{OH}$ and $\left[\mathrm{X}_{i}\right]$ is the concentration of that species. If there is no $\mathrm{OH}$ production, then the equation for the $\mathrm{OH}$ decay is

$$
\frac{\mathrm{d}[\mathrm{OH}]}{\mathrm{d} t}=-k_{\mathrm{OH}}[\mathrm{OH}] \text {. }
$$

The first direct measurements of $\mathrm{OH}$ reactivity were made in Nashville, TN, in summer 1999 (Kovacs et al., 2003). The measured $\mathrm{OH}$ reactivity exceeded the calculated $\mathrm{OH}$ reactivity by about $30 \%$, which was thought to come from shortlived highly reactive volatile organic compounds (VOCs) that were not measured in that study. The difference between the measured and calculated $\mathrm{OH}$ reactivity was referred to as the "missing" $\mathrm{OH}$ reactivity. For forest environments, the first evidence for missing $\mathrm{OH}$ reactivity came from direct $\mathrm{OH}$ reactivity measurements in a northern Michigan forest in summer 2000 (Di Carlo et al., 2004). As much as a third of the
$\mathrm{OH}$ reactivity was missing, with missing $\mathrm{OH}$ reactivity increasing with temperature in a manner identical to the expected increase of forest monoterpene emissions. Since then, $\mathrm{OH}$ reactivity has been measured many times in various urban, rural, and forest environments (Yang et al., 2016, and references therein). The fraction of missing $\mathrm{OH}$ reactivity in different forests varies from less than $20 \%$, which is approximately the uncertainty in the measured and calculated OH reactivity (Kaiser et al., 2016; Zannoni et al., 2016), to more than $50 \%$ (Nölscher et al., 2012, 2016). Considering the large numbers of trace gases emitted into the atmosphere (Goldstein and Galbally, 2007), it is possible that missing $\mathrm{OH}$ reactivity comes from $\mathrm{OH}$ reactants that were not measured or not included in previously calculated totals of the $\mathrm{OH}$ reactivity sum. In some studies, the $\mathrm{OH}$ reactants have been only those that were measured, and in other studies unmeasured but modeled $\mathrm{OH}$ reactants - such as organic peroxyl radicals and oxygenated volatile organic compound (OVOC) products - have been included. A recent intercomparison of several $\mathrm{OH}$ reactivity instruments demonstrated that these large missing $\mathrm{OH}$ reactivity values are probably not due to instrument issues (Fuchs et al., 2017). These discrepancies have yet to be resolved.

One regime that has yet to be adequately investigated is the remote marine boundary layer (MBL) and the free troposphere above it, which comprises $70 \%$ of the global lower troposphere. Two prior studies measured $\mathrm{OH}$ reactivity in the MBL. The most recent was shipborne across the Mediterranean Sea, through the Suez Canal, and into the Arabian Gulf in summer 2017 (Pfannerstill et al., 2019). Several portions of this journey were heavily influenced by petrochemical activity or ship traffic, while others were relatively clean. Median measured $\mathrm{OH}$ reactivity for the different waterways ranged from 6 to $13 \mathrm{~s}^{-1}$, while median calculated $\mathrm{OH}$ reactivity ranged from 2 to $9 \mathrm{~s}^{-1}$. When more than 100 measured chemical species were included in the calculated $\mathrm{OH}$ reactivity, the difference between the measured and calculated $\mathrm{OH}$ reactivity was reduced to being within measurement and calculation uncertainty for some regions, but significant missing $\mathrm{OH}$ reactivity remained for other regions. In the cleaner portions of the Mediterranean and Adriatic seas, the calculated $\mathrm{OH}$ reactivity of $\sim 2 \mathrm{~s}^{-1}$ was below the instrument's limit of detection $\left(\mathrm{LOD}=5.4 \mathrm{~s}^{-1}\right)$.

The other study involved airborne $\mathrm{OH}$ reactivity measurements made during the Intercontinental Chemical Transport Experiment Phase B (INTEX-B) study, a NASA airborne campaign investigating Asian-influenced pollution over the North Pacific Ocean in April-May 2006 (Mao et al., 2009). In this study, aged pollution plumes from Southeast Asia were encountered within large regions of relatively clean air. At altitudes below $\sim 2 \mathrm{~km}$, missing $\mathrm{OH}$ reactivity was $\sim 2.4 \mathrm{~s}^{-1}$, more than the calculated $\mathrm{OH}$ reactivity of $1.6 \pm$ $0.4 \mathrm{~s}^{-1}$. It decreased to within measurement uncertainty above $4 \mathrm{~km}$. The correlation of missing $\mathrm{OH}$ reactivity with formaldehyde $(\mathrm{HCHO})$ suggested that the missing $\mathrm{OH}$ reac- 
tivity was due to highly reactive VOCs that had $\mathrm{HCHO}$ as a reaction product. The confinement of the missing $\mathrm{OH}$ reactivity to the MBL and just above it suggested that the cause of the missing $\mathrm{OH}$ reactivity was ocean emissions of VOCs.

In this paper, we describe measurements of $\mathrm{OH}$ reactivity that were made during the NASA Atmospheric Tomography (ATom) campaign (ATom, 2016). This campaign took place in four month-long phases, each in a different season, between August 2016 and May 2018 and covered nearly all latitudes over the Pacific and Atlantic oceans. Although the calculated $\mathrm{OH}$ reactivity in the middle-to-upper troposphere is less than the $\mathrm{OH}$ reactivity instrument's LOD of $\sim 0.3 \mathrm{~s}^{-1}$ at $68 \%$ confidence, this instrument can measure $\mathrm{OH}$ reactivity in and just above the MBL. The comprehensive instrument suite deployed aboard the NASA DC-8 airborne laboratory allows a detailed examination of which trace gases most influence measured $\mathrm{OH}$ reactivity.

\section{Methods}

Here we discuss the ATom campaign, the $\mathrm{OH}$ reactivity instrument and its measurement capabilities, the model used to generate calculated $\mathrm{OH}$ reactivity, and the statistical analysis that was used to find correlations with missing $\mathrm{OH}$ reactivity.

\subsection{ATom}

The ATom campaign consisted of four deployments over all four seasons, starting with Northern Hemisphere summer in 2016 and ending with Northern Hemisphere spring in 2018 (Table 1).

Each deployment used the NASA DC-8 Airborne Science Laboratory to profile the atmosphere by frequently ascending and descending between 0.2 and $12 \mathrm{~km}$ on flights north from California to Alaska, south over the Pacific to New Zealand, east over the Southern Ocean to Chile, north over the Atlantic Ocean to Greenland, west over the Arctic Ocean to Alaska, and then back to California (yellow lines in Fig. 1). As shown in Table 2, the DC-8 carried a suite of instruments that measured over 100 different chemical constituents, aerosol particle properties and chemical composition, photolysis frequencies, and meteorological variables (Wofsy et al., 2018; ATom, 2016).

\subsection{OH reactivity measurement}

The $\mathrm{OH}$ reactivity concept and the basic instrument have been described before for ground-based operation (Kovacs and Brune, 2001) and for aircraft operation (Mao et al., 2009). The instrument used for ATom, called OH Reactivity (OHR), is a version of the one described by Mao et al. (2009). A brief description of the concept and the instrument is presented below.

Sampled air is brought into the instrument during flight by ram force at the $1.2 \mathrm{~cm}$ diameter inlet and the Venturi effect at the instrument outlet. A movable wand at the center of a flow tube $(7.5 \mathrm{~cm}$ diameter) injects $\mathrm{OH}$ into the flow tube at different distances from an $\mathrm{OH}$ detection inlet and axis similar to the one used to detect $\mathrm{OH}$ in the atmosphere. In the wand, $\mathrm{OH}$ is generated in a flow of humidified carrier $\left(\mathrm{N}_{2}\right.$ or purified air), which is exposed to $185 \mathrm{~nm}$ radiation from a $\mathrm{Hg}$ lamp that photolyzes the $\mathrm{H}_{2} \mathrm{O}$ to make $\mathrm{OH}$ and $\mathrm{HO}_{2}$. As the wand moves away from the detection axis, the signal observed of unreacted $\mathrm{OH}$ with the sample air decreases. Assuming a constant decay rate, measured $\mathrm{OH}$ reactivity is determined by Eq. (3):

$k_{\mathrm{OH}}=\frac{\ln \left(\frac{\left[\mathrm{OH}_{0}\right]}{[\mathrm{OH}]}\right)}{\Delta t}-k_{\text {offset }}$,

where $[\mathrm{OH}]$ is the instantaneous $\mathrm{OH}$ concentration, $\left[\mathrm{OH}_{0}\right]$ is the initial $\mathrm{OH}$ concentration, $\Delta t$ is reaction time between the $[\mathrm{OH}]$ measurements (the distance the wand moves divided by the flow speed), and $k_{\text {offset }}$ is the instrument offset due to $\mathrm{OH}$ loss to the walls or to impurities in the carrier gas. The wand moves approximately $10 \mathrm{~cm}$ in total along its path from closest point to farthest point from the detection axis. The sampling time step is synced with the Airborne Tropospheric Hydrogen Oxides Sensor (ATHOS, an instrument used in tandem with the OHR instrument to measure in situ $\mathrm{OH}$ and $\mathrm{HO}_{2}$ ), which samples at $5 \mathrm{~Hz}$. Depending on the ATom deployment, the wand takes 15 or $20 \mathrm{~s}$ to move $10 \mathrm{~cm}$ and back to its starting position, where it rests for 5 or $10 \mathrm{~s}$ while the $\mathrm{OH}$ detection system switches the laser wavelength off resonance with the $\mathrm{OH}$ absorption line to measure the signal background. Flow speeds through the OHR instrument are measured with a hot-wire anemometer and are typically between $0.25 \mathrm{~m} \mathrm{~s}^{-1}$ at lower altitudes and $0.45 \mathrm{~m} \mathrm{~s}^{-1}$ at higher altitudes, resulting in a typical total measured reaction time between 0.40 and $0.22 \mathrm{~s}$.

It is important to note that all $\mathrm{OH}$ reactivity instruments measure the "instantaneous" $\mathrm{OH}$ reactivity, which is only the reactions that occur within the maximum reaction time observed by that instrument. This maximum time is typically less than $1 \mathrm{~s}$. These instruments do not measure either subsequent $\mathrm{OH}$ reactivity or $\mathrm{OH}$ production if the time constants for that chemistry are greater than the maximum reaction time. In relatively clean environments, no subsequent chemistry affects the measured $\mathrm{OH}$ decay. However, in environments where $\mathrm{NO}$ is greater than a few parts per billion by volume (ppbv), the reaction $\mathrm{HO}_{2}+\mathrm{NO} \rightarrow \mathrm{OH}+\mathrm{NO}_{2}$ is fast enough to convert $\mathrm{HO}_{2}$ to $\mathrm{OH}$, thereby altering the observed $\mathrm{OH}$ decay. No high-NO environments were encountered in ATom.

In all previous ground-based and aircraft-based studies, high-purity $\mathrm{N}_{2}$ was used as the carrier gas in the wand. During aircraft-based studies, a cylinder of $\mathrm{N}_{2}$ gas was consumed on each $8 \mathrm{~h}$ flight and accordingly had to be replaced before the next flight. It was not possible to position caches of $\mathrm{N}_{2}$ cylinders at each of the $\sim 12$ layovers during each ATom 
Table 1. ATom campaign deployment seasons and start and end dates. Full details on stops can be found online (ATom, 2016).

\begin{tabular}{lllll}
\hline Deployment & ATom1 & ATom2 & ATom3 & ATom4 \\
\hline NH season & Summer & Winter & Fall & Spring \\
Start date & 28 Jul 2016 & 26 Jan 2017 & 28 Sep 2017 & 24 Apr 2018 \\
End date & 22 Aug 2016 & 22 Feb 2017 & 26 Oct 2017 & 21 May 2018 \\
\hline
\end{tabular}
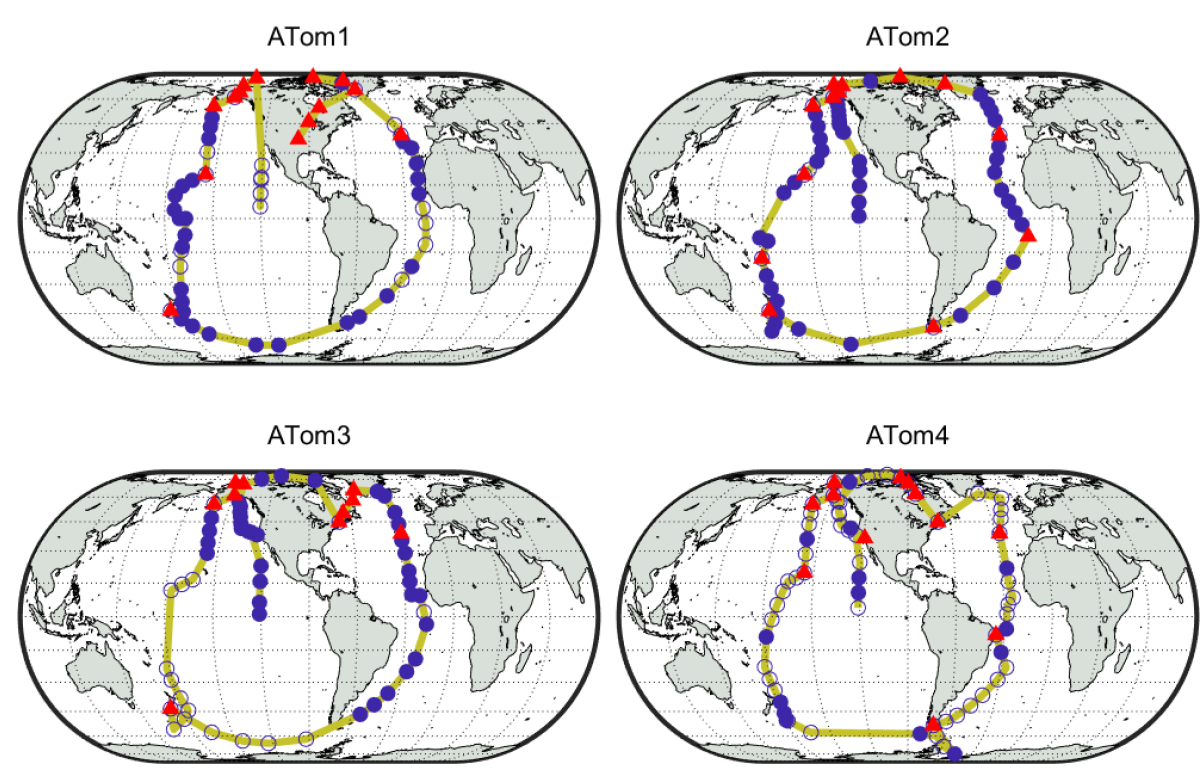

Figure 1. Global ATom tracks (yellow lines) with indicators for the periods during which the DC-8 dipped into the boundary layer. Filled blue circles indicate points used for analysis, filled red triangles indicate dips when over land, and unfilled blue circles indicate dips not used for analysis due to instrument calibrations or downtime.

phase. Instead of $\mathrm{N}_{2}$, air from a zero-air generator (PermaPure ZA-750-12) was used as the carrier gas in the laboratory prior to ATom. Before each mission, the zero-air generator medium (PermaPure ZA AR - activated carbon and alumina mixture) was replaced and the air produced by the unit was verified to be pure by running it through a potential aerosol mass chamber that rapidly oxidizes any VOCs to particles (Lambe et al., 2011). No particles were seen, indicating that the air had negligible amounts of larger reactive VOCs. The results of this test were consistent with those obtained by substituting the air from the zero-air generator with high-purity nitrogen. The exception to this procedure was during ATom4, when the zero-air generator itself had to be replaced late in the instrument integration period. The medium was changed prior to the ATom4 integration and the research flights, but the air purity was unable to be checked until after the ATom4 deployment had ended, when it was found that the OHR offset was higher than in previous ATom deployments.

\subsection{OH reactivity measurement offset calibrations}

The OHR offset varied between the four ATom deployments due to changes in the zero-air generator performance and between research flights due to internal contamination from pre-flight conditions. These changes were tracked with measurements of the OHR instrument offset in the laboratory and, for ATom4, in situ during several flights. For the laboratory calibrations, the internal pressure of the OHR instrument was varied between 30 and $100 \mathrm{kPa}$ to simulate inflight conditions. For the in situ calibrations taken during the second half of ATom4, the OHR instrument was switched from sampling the ambient flow to sampling high-purity $\mathrm{N}_{2}$ from a reserve $\mathrm{N}_{2}$ cylinder. The flow rate out of the cylinder was adjusted to match the flow speed measured by the hot-wire anemometer just prior to the switch. During ascent and descent, the internal pressure and flow speed changed too quickly over the length of one decay to get good offset calibrations, so offset calibrations were taken only from stable altitude legs, predominantly at the low altitudes.

Two complete laboratory calibrations, the in situ calibration, and a calibration only at $\sim 100 \mathrm{kPa}$ were used to determine $k_{\text {offset }}$ for the different ATom deployments (Fig. 2). The 2017 calibration applies to ATom2 and ATom3, while the 2018 calibration applies to ATom4. For ATom1, the offset was calibrated at only $97 \mathrm{kPa}$ prior to the mission, but it is in excellent agreement with the offset calibrated for ATom4. We can safely assume that the ATom4 offset slope 
Table 2. Simultaneous measurements used to constrain the box model and calculate $\mathrm{OH}$ reactivity.

\begin{tabular}{|c|c|c|c|}
\hline Measurement & Instrument & Uncertainty ( $2 \sigma$ confidence) & Reference \\
\hline$T$ & Meteorological Measurement & $\pm 0.5 \mathrm{C}$ & Chan et al. (1998) \\
\hline$p$ & System (MMS) & $\pm 0.3 \mathrm{hPa}$ & \\
\hline $\mathrm{H}_{2} \mathrm{O}$ & Diode Laser Hygrometer (DLH) & $\pm 15 \%$ & Diskin et al. (2002) \\
\hline $\begin{array}{l}\text { Photolysis frequencies } \\
\text { (30 measurements) }\end{array}$ & $\begin{array}{l}\text { CCD Actinic Flux } \\
\text { Spectroradiometers (CAFS) }\end{array}$ & $\begin{array}{l} \pm(12-25) \% \\
\text { species dependent }\end{array}$ & Shetter and Mueller (1999) \\
\hline $\mathrm{NO}, \mathrm{NO}_{2}$ & Nitrogen Oxides and Ozone $\left(\mathrm{NO}_{y} \mathrm{O}_{3}\right)$ & $6.6,34 \mathrm{pptv}$ & Ryerson et al. (2000) \\
\hline $\mathrm{O}_{3}$ & $\begin{array}{l}\mathrm{NO}_{y} \mathrm{O}_{3}{ }^{*} \\
\text { UAS Chromatograph for Atmospheric } \\
\text { Trace Species (UCATS) }\end{array}$ & $\begin{array}{l}1.4 \mathrm{ppbv} \\
\pm 1 \%+1.5 \mathrm{ppbv}\end{array}$ & Ryerson et al. (2000) \\
\hline $\mathrm{CO}$ & $\begin{array}{l}\text { Quantum Cascade Laser } \\
\text { System (QCLS)* } \\
\text { NOAA Picarro } \\
\text { UCATS }\end{array}$ & $\begin{array}{l}3.5 \mathrm{ppbv} \\
3.6 \mathrm{ppbv} \\
8.4 \mathrm{ppbv}\end{array}$ & $\begin{array}{l}\text { Santorini et al. (2014) } \\
\text { Chen et al. (2013) }\end{array}$ \\
\hline $\begin{array}{l}\mathrm{H}_{2} \mathrm{O}_{2}, \mathrm{CH}_{3} \mathrm{OOH}, \mathrm{HNO}_{3} \\
\mathrm{CH}_{3} \mathrm{CO}_{3} \mathrm{H} \\
\mathrm{SO}_{2}\end{array}$ & $\begin{array}{l}\text { Caltech Chemical } \\
\text { Ionization Spectrometer } \\
\text { (CIT CIMS) }\end{array}$ & $\begin{array}{l} \pm 30 \%+50 \mathrm{pptv} \\
\pm 30 \%+100 \mathrm{pptv}\end{array}$ & Crounse et al. (2006) \\
\hline $\mathrm{HCOOH}, \mathrm{BrO}$ & $\begin{array}{l}\text { NOAA Chemical Ionization } \\
\text { Spectrometer (CIMS) }\end{array}$ & $\pm 15 \%+50 \mathrm{pptv}$ & Neuman et al. (2016) \\
\hline $\mathrm{CH}_{4}$ & $\begin{array}{l}\text { NOAA Picarro* } \\
\text { UCATS } \\
\text { PAN and Trace Hydrohalocarbon } \\
\text { ExpeRiment (PANTHER) }\end{array}$ & $\begin{array}{l}0.7 \mathrm{ppbv} \\
23.6 \mathrm{ppbv} \\
34.6 \mathrm{ppbv}\end{array}$ & Karion et al. (2013) \\
\hline $\mathrm{HCHO}$ & $\begin{array}{l}\text { NASA In Situ Airborne } \\
\text { Formaldehyde (ISAF) }\end{array}$ & $\pm 10 \% \pm 10 \mathrm{pptv}$ & Cazorla et al. (2015) \\
\hline $\begin{array}{l}\text { Methyl nitrate, ethyl } \\
\text { nitrate, isoprene, acetylene, } \\
\text { ethylene, ethane, propane, } \\
\text { i-butane, n-butane, i- } \\
\text { pentane, n-pentane, n- } \\
\text { hexane, n-heptane, } \\
\text { benzene, toluene, methyl } \\
\text { chloride, methylene } \\
\text { chloride, chloroform, } \\
\text { methyl bromide, methyl } \\
\text { chloroform, } \\
\text { perchloroethene, 1,2- } \\
\text { dichloroethane, DMS }\end{array}$ & $\begin{array}{l}\text { University of California, Irvine } \\
\text { Whole Air Sampler (UCI WAS) }\end{array}$ & $\pm 10 \%$ & Colman et al. (2001) \\
\hline $\begin{array}{l}\text { Methanol, formaldehyde, } \\
\text { acetaldehyde, ethyl } \\
\text { benzene, toluene, } \\
\text { methacrolein, methyl ethyl } \\
\text { ketone, methyl tert-butyl } \\
\text { ether, ethanol, acetone, 2- } \\
\text { methylpentane, 3- } \\
\text { methylpentane, 2,2,4- } \\
\text { trimethylpentane, } \\
\text { isobutene+1-butene,m- } \\
\text { xylene+p-xylene, o-xylene, } \\
\text { tricyclene, limonene+D3- } \\
\text { carene, propanal, butanal, } \\
\text { acrolein }\end{array}$ & Trace Organic Gas Analyzer (TOGA) & $\begin{array}{l} \pm 15 \%-50 \% \\
\text { (acetaldehyde: } \pm 20 \% \text { ) }\end{array}$ & Apel et al. (2015) \\
\hline
\end{tabular}

* Primary measurement. Other measurements fill gaps in primary measurement. 


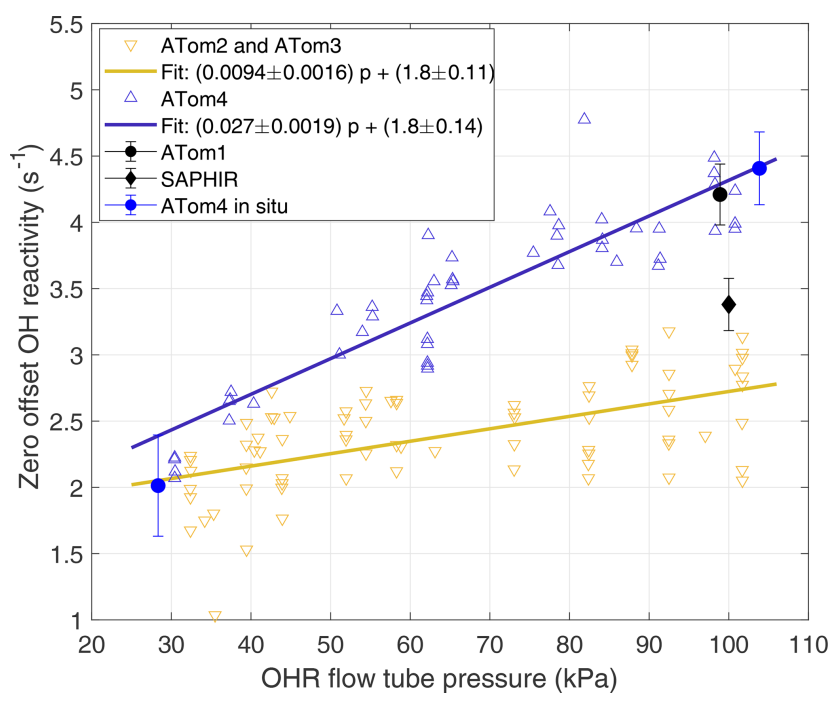

Figure 2. Laboratory and in situ calibrations of OHR offset over 1 min sums. The offset was calibrated only at $\sim 100 \mathrm{kPa}$ around ATom1 in 2015 and 2016 (black dot). The offset was measured with a slightly different instrument configuration during the $\mathrm{OH}$ reactivity intercomparison study in 2015 (black diamond) (Fuchs et al., 2017). Shown are offset calibrations performed in 2017 between ATom 2 and ATom 3 (yellow inverted triangles) and their linear fit (yellow line), in 2018 at the end of ATom4 (blue triangles) and their linear fit (blue line), and in flight (blue dots). Error bars are \pm 1 standard deviation of the mean. The ATom 4 fit was used for ATom 1 because the high-pressure laboratory calibrations were essentially the same.

can be applied to ATom1 because all offset calibrations performed at low OHR flow tube pressures, even those of Mao et al. (2009), give $\sim 2 \mathrm{~s}^{-1}$ for the offset value. The difficulty of maintaining steady calibration conditions in flight during ATom 4 caused the large in situ calibration error. The standard deviation of these in situ offset calibrations is $0.75 \mathrm{~s}^{-1}$, which is 2.5 to 3 times larger than the standard deviation obtained for ambient measurements in clean air for the same altitude and number of measurements, indicating that the atmospheric measurement precision is much better than could be achieved in these difficult offset calibrations. Yet even with this lower precision, the mean in situ offset at high and low pressure agrees with the linear fit of the laboratory calibrations to within $20 \%$ at low pressures and $3 \%$ at high pressure. The excellent agreement between the laboratory and in situ offset calibrations for ATom4 confirms the finding of Mao et al. (2009) that laboratory offset calibrations before or after a campaign accurately capture the instrument offset during the campaign.

This observed pressure dependence of the offset calibration is different from the behavior of the pressureindependent offset calibration used by Mao et al. (2009). However, a re-examination of the Mao et al. (2009) data indicates that the offset during INTEX-B was also pressure dependent, with an offset of $2.9 \mathrm{~s}^{-1}$ at high OHR flow tube pressure and $2.0 \mathrm{~s}^{-1}$ at low OHR flow tube pressure, nearly identical to the values used for ATom 2 and ATom3.

The difference in the linear fit to the offset calibration for ATom 1 and ATom 4 and the linear fit to the offset calibration for ATom 2 and ATom 3 is pressure dependent (Fig. 2). The standard volume airflow in the wand was constant, but the ambient volume flow in the flow tube decreased by a factor of $\sim 2$ as the flow tube pressure increased from 30 to $100 \mathrm{kPa}$. As a result, the contamination concentration from the wand air also increased by a factor of $\sim 2$ as flow tube pressure increased. This pressure-dependent contamination concentration explains much of the difference between the two fitted lines and provides evidence that contamination in the wand flow was a substantial contributor to the changes in the zero offset in ATom1 and ATom4 and that in ATom2 and ATom3. The good agreement between the fit for ATom2 and ATom3 and the offset calibrations of Mao et al. (2009), who used ultra-high-purity $\mathrm{N}_{2}$, suggests that the zero air for ATom 2 and ATom 3 had negligible contamination.

The OHR instrument zero offset varied slightly from flight to flight because of the variable air quality produced by the zero-air generator. This flight-to-flight variation was tracked and the $\mathrm{OH}$ reactivity offset was corrected by the following procedure. The $\mathrm{OH}$ reactivity calculated from the model at the OHR instrument's temperature and pressure (see Sect. 2.5) was $0.25-0.30 \mathrm{~s}^{-1}$ for the upper troposphere during all ATom deployments and latitudes. The offset calibrations were adjusted in the range of $0.34 \pm 0.32 \mathrm{~s}^{-1}$ for each research flight by a pressure-invariant offset that was necessary to equate the mean measured and model-calculated $\mathrm{OH}$ reactivity values for data taken above $8 \mathrm{~km}$ altitude. If this offset correction is not used for all altitudes, then the $\mathrm{OH}$ reactivity in the $2-8 \mathrm{~km}$ range varies unreasonably from flight to flight, even going significantly negative at times. In effect, we used the upper troposphere as a clean standard in order to fine-tune $k_{\text {offset }}$, just as Mao et al. (2009) did.

The $\mathrm{OH}$ signals in the upper troposphere were high enough to allow the slopes of the $\mathrm{OH}$ decays to be determined with good precision for each 20-30 s decay. However, at the low altitudes, quenching of the fluorescence signal by higher air and water vapor abundances reduced the $\mathrm{OH}$ signals. To compensate for this reduction, decays were binned into $1 \mathrm{~min}$ sums before the decay slopes were calculated. Three $\mathrm{OH}$ signal decays from low altitudes during ATom 2 are shown in Fig. 3. When $k_{\text {offset }}$ is subtracted from the decays shown in Fig. 3, their values become $\sim 5$ (blue), $\sim 3$ (teal), and $\sim 2 \mathrm{~s}^{-1}$ (yellow).

\subsection{Missing $\mathrm{OH}$ reactivity uncertainty analysis}

The uncertainty for missing $\mathrm{OH}$ reactivity in the $\mathrm{MBL}$ at the $68 \%$ confidence level comes from four components: the decay measurement itself; the offset as determined by the slope and intercepts of the fits to the laboratory $\mathrm{OH}$ reactivity off- 


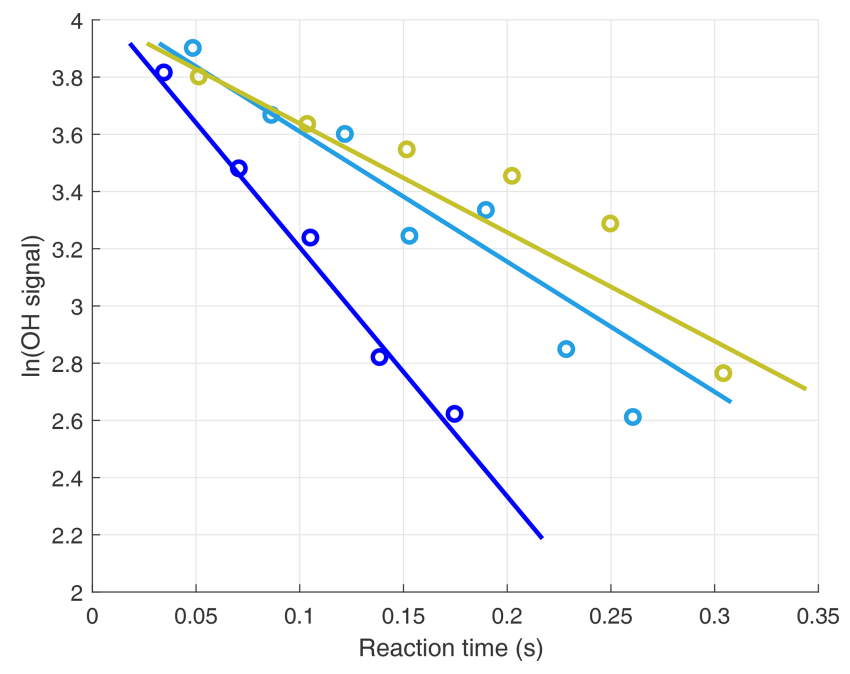

Figure 3. Three in-flight decays for $1 \mathrm{~min}$ sums of the $\mathrm{OH}$ signals. Decays were measured in the marine boundary layer, and the individual $5 \mathrm{~Hz}$ data were binned by reaction times for clarity. When $k_{\text {offset }}$ is subtracted from the decays, their values become $\sim 5$ (blue), $\sim 3$ (teal), and $\sim 2$ (yellow) $\mathrm{s}^{-1}$.

set calibrations (Fig. 2); the flight-to-flight offset variation as judged by fitting the measured $\mathrm{OH}$ reactivity to the modelcalculated $\mathrm{OH}$ reactivity at $8-12 \mathrm{~km}$ altitude; and the model calculations. First, the uncertainty in decay fit is approximately $\pm 7.5 \%$, which for a typical $\mathrm{OH}$ reactivity measurement in the MBL of $\sim 2 \mathrm{~s}^{-1}$ would give an uncertainty of $\pm 0.15 \mathrm{~s}^{-1}$. Second, the uncertainty in the $\mathrm{OH}$ reactivity offset in the MBL is found from the sum of the slope uncertainty multiplied by the OHR flow tube pressure, which is $\sim 100 \mathrm{kPa}$ in the MBL, $\left( \pm 0.16 \mathrm{~s}^{-1}\right)$ and the intercept uncertainty $\left( \pm 0.11 \mathrm{~s}^{-1}\right)$. The two uncertainties are assumed to be correlated. Third, the uncertainty in the flight-to-flight offset variation is the standard deviation of the mean for each highaltitude level leg $\left( \pm 0.15 \mathrm{~s}^{-1}\right)$. Fourth, the uncertainty of the model-calculated $\mathrm{OH}$ reactivity was determined by Eq. (4):

$\Delta k_{\mathrm{OH}}^{\text {calc }}\left(\mathrm{s}^{-1}\right)=\sqrt{\sum\left[\left(k_{i} \Delta x_{i}\right)^{2}+\left(\Delta k_{i} x_{i}\right)^{2}\right]}$,

where $k_{i}$ are the reaction rate coefficients and $x_{i}$ are the $\mathrm{OH}$ reactant concentrations. The rate coefficient uncertainties come from Burkholder et al. (2016), and the chemical species uncertainties come from Table 2 and Brune et al. (2020). For the 11 chemical species responsible for $95 \%$ of the total $\mathrm{OH}$ reactivity in the MBL, this uncertainty is $\pm 0.08 \mathrm{~s}^{-1}$. The square root of the sum of the squares of all these uncertainties yields a total uncertainty for the MBL missing $\mathrm{OH}$ reactivity of $\pm 0.32 \mathrm{~s}^{-1}$ at the $68 \%$ confidence level.

The $\mathrm{OH}$ reactivity from the model at the ambient temperature and pressure rarely exceeded $2 \mathrm{~s}^{-1}$ in the planetary boundary and was only $0.2 \mathrm{~s}^{-1}$ in the free troposphere. These low values presented a significant challenge for our
OHR instrument, as it would have for any $\mathrm{OH}$ reactivity instrument; even the most precise instrument measuring in a chamber at its home laboratory has a LOD of $\pm 0.2 \mathrm{~s}^{-1}(68 \%$ confidence) for a measurement integration time of 60-160 s (Fuchs et al., 2017). If the same instrument were to sample air masses on an aircraft traveling $200 \mathrm{~m} \mathrm{~s}^{-1}$, its precision would likely be degraded. From this perspective, the LOD on these ATom measurements is about as low as that for any other $\mathrm{OH}$ reactivity measurements.

The analysis in the paper is focused on the first three ATom deployments. ATom 4 is excluded from this analysis for two reasons. First, offset calibrations were performed during more than half of the low-altitude periods over the Atlantic, severely limiting the ambient measurements in the MBL. Second, the increased contamination during ATom4 made the $\mathrm{OH}$ reactivity measurements 2-3 times noisier than during the previous ATom deployments.

\subsection{Photochemical box model}

The photochemical box model used to calculate $\mathrm{OH}$ reactivity is the Framework for 0-D Atmospheric Modeling (F0AM) (Wolfe et al, 2016). It uses the Master Chemical Mechanism v3.3.1 (MCMv331) for all gas-phase reactions (Jenkin et al., 1997, 2003; Saunders et al., 2003). Both the F0AM model framework and MCMv3.3.1 are publicly available. The reactions of $\mathrm{CH}_{3} \mathrm{O}_{2}+\mathrm{OH}$ and $\mathrm{C}_{2} \mathrm{H}_{5} \mathrm{O}_{2}+\mathrm{OH}$ were added to the model mechanism with rate coefficients from Assaf et al. (2017). The model was run with the integration time set to $3 \mathrm{~d}$ with a first-order dilution lifetime of $12 \mathrm{~h}$, although the calculated $\mathrm{OH}$ reactivity was the same to within a few percent for an order-of-magnitude change in these times. The model was constrained by the simultaneous measurements listed in Table 2. These measurements were taken from the $1 \mathrm{~s}$ merge file, averaged to $1 \mathrm{~min}$ values, and interpolated to a common 1 min time step. In cases where multiple measurements of a chemical species exist (e.g., CO), a primary measurement was chosen and other measurements were used to fill gaps in the primary measurement.

To compare measured and calculated $\mathrm{OH}$ reactivity, the model-calculated $\mathrm{OH}$ reactivity must be corrected to the OHR flow tube pressure and temperature. For the rest of this paper, "calculated $\mathrm{OH}$ reactivity" will refer to these corrected values. Equation (1) was then used to find the calculated $\mathrm{OH}$ reactivity. If the measured and calculated $\mathrm{OH}$ reactivity agreed, then there was no missing $\mathrm{OH}$ reactivity to within the uncertainties for both the measured and the calculated values. However, if there was missing $\mathrm{OH}$ reactivity in the flow tube, then the missing $\mathrm{OH}$ reactivity in the atmosphere may be different because the temperature dependence of its reaction rate coefficients is unknown. Fortunately, the focus of this study is in and just above the MBL, where the flow tube pressures and temperatures are nearly identical to atmospheric temperatures and pressures. The $\mathrm{OH}$ reactivity calculated from the model output at the flow tube pressure 
and temperature is within $\pm 10 \%$ of that calculated at ambient conditions. Thus, the missing $\mathrm{OH}$ reactivity at the flow tube temperature and pressure is assumed to be equal to the atmospheric missing $\mathrm{OH}$ reactivity.

If missing $\mathrm{OH}$ reactivity is found, a likely source is unknown VOCs or OVOCs, which we will call X. The abundance of $\mathrm{X}$ was determined from the missing $\mathrm{OH}$ reactivity by Eq. (5):

$X=\frac{\mathrm{mOHR}}{k_{\mathrm{X}+\mathrm{OH}}} \frac{10^{9}}{M}$,

where $X$ is the missing chemical species mixing ratio (ppbv), mOHR is the missing $\mathrm{OH}$ reactivity, $k_{\mathrm{X}+\mathrm{OH}}$ is the reaction rate coefficient for the reaction $\mathrm{X}+\mathrm{OH} \rightarrow$ products, and $M$ is the air number concentration. We assume that $k_{\mathrm{X}+\mathrm{OH}}=$ $10^{-10} \mathrm{~cm}^{3} \mathrm{~s}^{-1}$, which gives $\mathrm{X}$ a lifetime of about $1 \mathrm{~h}$ for the typical daytime $[\mathrm{OH}]$ of $\sim 3 \times 10^{6} \mathrm{~cm}^{-3}$. For these assumptions, an X abundance of $400 \mathrm{pptv}$ (parts per trillion by volume) corresponds to a missing OH reactivity of $1 \mathrm{~s}^{-1}$. This arbitrary rate coefficient approximates a rate coefficient for a reaction of a sesquiterpene with $\mathrm{OH}$. If $\mathrm{X}$ is an alkane or alkene that has a lower reaction rate coefficient, then the required $\mathrm{X}$ abundance will be larger.

Simple X oxidation chemistry was added to the photochemical mechanism to test the impact of $\mathrm{X}$ on the modeled $\mathrm{OH}$ and $\mathrm{HO}_{2}$. This assumed additional chemistry is provided in Table 3. $\mathrm{XO}_{2}$ is used to designate the peroxy radical formed from X. Rate coefficients for $\mathrm{CH}_{3} \mathrm{O}_{2}$ and $\mathrm{CH}_{3} \mathrm{OOH}$ were assumed to apply to $\mathrm{XO}_{2}$ and $\mathrm{XOOH}$. Case one assumes that no $\mathrm{OH}$ is regenerated in the oxidation sequence for $\mathrm{X}$, while case two assumes that $\mathrm{OH}$ is regenerated for every oxidation sequence of $\mathrm{X}$.

\subsection{Correlation analysis}

An analysis of correlations between missing $\mathrm{OH}$ reactivity and the chemical or environmental factors could indicate possible causes of the missing $\mathrm{OH}$ reactivity. Linear regressions were found for missing $\mathrm{OH}$ reactivity and every measured and calculated chemical species and meteorological parameter. Calculated chemical species with abundances less than 1 pptv were not included in the regressions. Sea surface temperature (SST) and chlorophyll data come from NASA Earth Observations (2019). Correlations were performed on the first three ATom deployments individually and the first three ATom deployments combined.

To reduce the noise in the missing $\mathrm{OH}$ reactivity values prior to doing any correlation analysis, the $1 \mathrm{~min}$ missing $\mathrm{OH}$ reactivity values were averaged into "per-dip" bins and "per-flight" bins. The term "per-dip" means that the missing $\mathrm{OH}$ reactivity was averaged over each $5 \mathrm{~min}$ level-altitude leg at $160 \mathrm{~m}$. The standard deviation of the $1 \mathrm{~min}$ measurements within each dip was typically $0.4 \mathrm{~s}^{-1}$, while the standard deviation of the per-dip measurements in a flight was $0.25 \mathrm{~s}^{-1}$. The low-level legs used for the per-dip means were gener- ally in the MBL because its height was greater than $160 \mathrm{~m}$ $85 \%$ of the time. The MBL height is the altitude below which the potential temperature is constant. A per-dip bin occurred roughly every hour of flight. The term "per-flight" means that the missing $\mathrm{OH}$ reactivity for all the dips in a flight was averaged together. Each per-flight bin is the mean of each flight's per-dip set. Each per-flight bin spanned only a few degrees of latitude near the poles but as much as $50^{\circ}$ of latitude in the tropics. Only the measurements made while flying over the ocean were included in the per-dip and per-flight averaging because the dips over land sampled terrestrial or ice emissions and not ocean emissions.

Individual measured or calculated meteorological parameters and chemical species passed a preliminary correlation threshold for missing $\mathrm{OH}$ reactivity if the sign of each regression was the same for ATom1, ATom2, and ATom3. Correlations that passed this preliminary filter had their $R^{2}$ values averaged between each deployment individually and grouped together. The averaged correlation coefficients were then tallied and ranked from greatest to least $R^{2}$. The top $10 \%$ of these correlations for both the per-dip and per-flight averages were combined into one data set. Because the missing $\mathrm{OH}$ reactivity showed some latitude dependence, the same multistep technique was performed on all the chemical species and meteorological parameters in different hemispheres: Northern, Southern, Eastern, and Western. Both data sets were then combined into a single data set, and the strongest of these correlations were reported.

\section{Results}

The focus of these results is the $\mathrm{OH}$ reactivity measurements in and just above the MBL. However, the $\mathrm{OH}$ reactivity measurements are shown for the entire range of altitudes, even though the high-altitude $(>8 \mathrm{~km}) \mathrm{OH}$ reactivity values were set to the calculated $\mathrm{OH}$ reactivity that was corrected to the OHR flow tube pressure and temperature.

\subsection{Global $\mathrm{OH}$ reactivity versus altitude}

The average calculated global $\mathrm{OH}$ reactivity at the lowest altitudes is about an order of magnitude less than the average $\mathrm{OH}$ reactivity in cities or forests (Yang et al., 2016), which is typically $10-50 \mathrm{~s}^{-1}$. For ATom, calculated $\mathrm{OH}$ reactivity is less than $2 \mathrm{~s}^{-1}$ averaged over all latitudes and seasons (Fig. 4). In different seasons and regions, this calculated $\mathrm{OH}$ reactivity consists of $\mathrm{CO}(30-40 \%), \mathrm{CH}_{4}(19-$ $24 \%$ ), methyl hydroperoxide (MHP) (5-16\%), aldehydes (11-12\%), $\mathrm{H}_{2}(6-7 \%), \mathrm{O}_{3}(2-5 \%), \mathrm{HO}_{2}(2-6 \%), \mathrm{H}_{2} \mathrm{O}_{2}(0$ $5 \%$ ), and $\mathrm{CH}_{3} \mathrm{O}_{2}(0-7 \%)$, with the remaining reactants totaling less than $10 \%$. The ordering of these reactants is similar to that of Mao et al. (2009), although in their work the calculated $\mathrm{OH}$ reactivity due to $\mathrm{CO}$ was about $60 \%$, that due to $\mathrm{CH}_{4}$ about $15 \%$, and that due to all OVOCs about $16 \%$. 
Table 3. Simple $\mathrm{X}$ photochemistry added to the photochemical mechanism to test for effects of $\mathrm{X}$ on modeled $\mathrm{OH}_{\text {and }} \mathrm{HO}_{2}$.

\begin{tabular}{ll}
\hline Reaction & Reaction rate coefficient $\left(\mathrm{cm}^{3} \mathrm{~s}^{-1}\right)$ \\
\hline Case one: $\mathrm{X}+\mathrm{OH} \rightarrow \mathrm{XO}_{2}$ & $1 \times 10^{-10}$ \\
Case two: $\mathrm{X}+\mathrm{OH} \rightarrow \mathrm{XO}_{2}+\mathrm{OH}$ & \\
$\mathrm{X}+\mathrm{O}_{3} \rightarrow \mathrm{XO}_{2}$ & $1 \times 10^{-16}$ \\
$\mathrm{XO}_{2}+\mathrm{NO} \rightarrow \mathrm{HO}_{2}+\mathrm{NO}_{2}+$ prod & $3 \times 10^{-12} \exp (300 / T)$ \\
$\mathrm{XO}_{2}+\mathrm{HO}$ & $\rightarrow \mathrm{XOOH}$ \\
$\mathrm{XOOH}+h v \rightarrow \mathrm{XO}+\mathrm{OH}$ & $8.6 \times 10^{-13} \exp (700 / T)$ \\
$\mathrm{XOOH}+\mathrm{OH} \rightarrow \mathrm{XO}_{2}$ & $\mathrm{~J}_{\mathrm{CH}_{3} \mathrm{OOH}}\left(\mathrm{s}^{-1}\right)$ \\
\hline
\end{tabular}
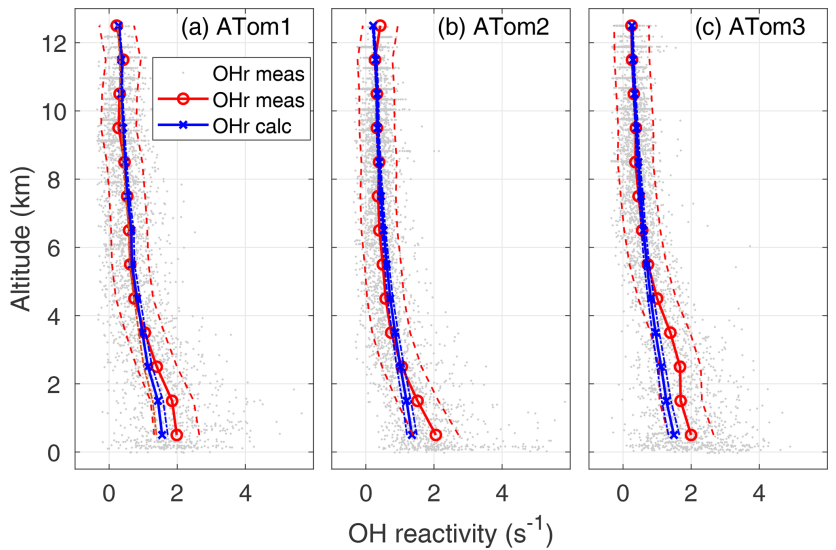

Figure 4. OH reactivity versus altitude for ATom1 (August), ATom2 (February), and ATom3 (October). One-minute measured $\mathrm{OH}$ reactivity (gray dots), median measured $\mathrm{OH}$ reactivity ( $\mathrm{OHr}$ meas) in $1 \mathrm{~km}$ altitude bins (red circle and line), median calculated $\mathrm{OH}$ reactivity (OHr calc) in $1 \mathrm{~km}$ altitude bins (blue $\mathrm{x}$ 's and line), and absolute OHR uncertainty (95\% confidence level) for measured and calculated $\mathrm{OH}$ reactivity (dashed lines) are shown as a function of altitude.

Part of this difference can be ascribed to more OVOC measurements in ATom and the greater $\mathrm{CO}$ abundances in the Northern Hemisphere, where INTEX-B occurred.

The calculated $\mathrm{OH}$ reactivity decreases from $\sim 1.5$ in the MBL to $0.25-0.30 \mathrm{~s}^{-1}$ in the upper troposphere (Fig. 4). The mean measured $\mathrm{OH}$ reactivity has been matched to the mean calculated $\mathrm{OH}$ reactivity for altitudes above $8 \mathrm{~km}$, but the two are independent at lower altitudes. The mean measured and calculated $\mathrm{OH}$ reactivity agree to within combined uncertainties for altitudes between $8 \mathrm{~km}$ and $2-4 \mathrm{~km}$, but the mean measured $\mathrm{OH}$ reactivity becomes increasingly greater than the mean calculated $\mathrm{OH}$ reactivity below $2-4 \mathrm{~km}$ and especially in the MBL. However, comparing the differences in the mean values is not the best way to understand these differences between measured and calculated $\mathrm{OH}$ reactivity.

\subsection{Missing $\mathrm{OH}$ reactivity: statistical evidence}

A better approach is to find the missing $\mathrm{OH}$ reactivity for each measurement point and then compare the mean values. The missing $\mathrm{OH}$ reactivity is plotted as a function of altitude for ATom1, ATom2, and ATom3 (Fig. 5). The mean missing $\mathrm{OH}$ reactivity is set to $0 \mathrm{~s}^{-1}$ for $8-12 \mathrm{~km}$, remains near to 0 from 8 to $2-4 \mathrm{~km}$, and increases below $2-4 \mathrm{~km}$. The $1 \mathrm{~min}$ measurements are a good indicator of the measurement precision, which is $\pm 0.35 \mathrm{~s}^{-1}$ for ATom 1 and $\pm 0.25 \mathrm{~s}^{-1}$ for ATom2 and ATom3.

In the MBL, the mean missing $\mathrm{OH}$ reactivity is $0.4 \mathrm{~s}^{-1}$ for ATom1, $0.5 \mathrm{~s}^{-1}$ for ATom3, and $0.7 \mathrm{~s}^{-1}$ for ATom2. From a Student $t$ test in which the MBL missing $\mathrm{OH}$ reactivity is compared to the values in either the $6-8$ or $8-12 \mathrm{~km}$ altitude range, the differences in mean missing $\mathrm{OH}$ reactivity between the MBL and the higher altitudes is statistically significant for a significance level, $\alpha$, equal to 0.01 , with $p$ values $<10^{-15}$. However, the mean MBL missing $\mathrm{OH}$ reactivity values are close to the upper limit on the absolute missing $\mathrm{OH}$ reactivity uncertainty ( $95 \%$ confidence), which is $0.64 \mathrm{~s}^{-1}$ (blue bar, Fig. 5). There is a small probability (2-10\%) that the mean MBL missing $\mathrm{OH}$ reactivity is due only to absolute error in the missing $\mathrm{OH}$ reactivity measurement that was derived in Sect. 2.4.

The mean MBL missing $\mathrm{OH}$ reactivity contains measurements for which the missing $\mathrm{OH}$ reactivity is $0 \mathrm{~s}^{-1}$. The real interest is in the missing $\mathrm{OH}$ reactivity that is greater than can be explained by absolute missing $\mathrm{OH}$ reactivity measurement error or precision. From Fig. 5, it is clear that the positive scatter of data is much greater than the negative scatter. The means of standard deviations of the negative values and of the positive values were calculated for $1 \mathrm{~km}$ height intervals (dashed lines). These lines and the individual data points both indicate skewness in the missing $\mathrm{OH}$ reactivity, especially in the lowest $2-4 \mathrm{~km}$ altitude. A skewness test shows that, in and just above the MBL, missing $\mathrm{OH}$ reactivity from ATom1 and ATom3 exhibits weak to moderate skewness $(\sim 0.4)$, while missing OH reactivity from ATom2 exhibits strong skewness (1.4).

Quantile-quantile plots (Q-Q plots) provide a visual description of the relationship between a sample distribution 


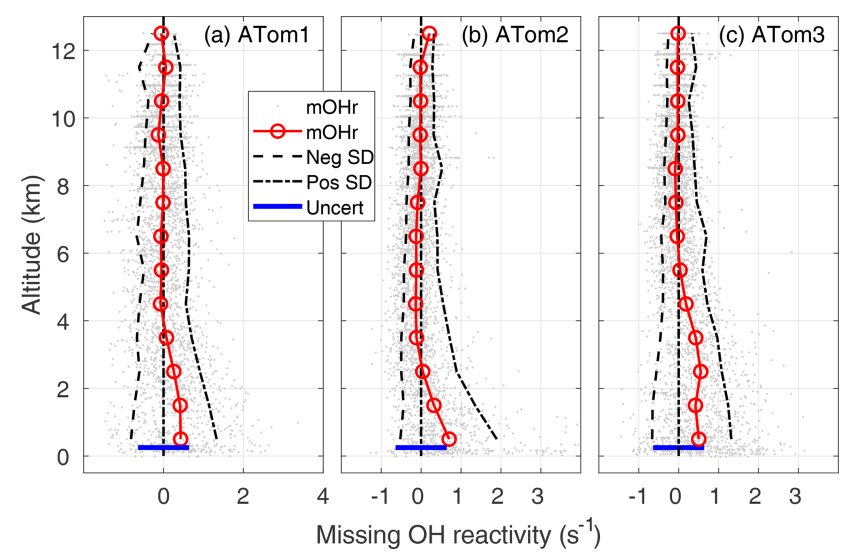

Figure 5. Missing OH reactivity (mOHr) against altitude for ATom 1 (August), ATom2 (February), and ATom3 (October). Gray dots are the $\mathrm{OH}$ reactivity calculated by subtracting calculated $\mathrm{OH}$ reactivity from measured $\mathrm{OH}$ reactivity. Median missing $\mathrm{OH}$ reactivity below $1 \mathrm{~km}$ altitude (red circles and lines) is comparable to the absolute uncertainty in the missing $\mathrm{OH}$ reactivity (blue bar, $95 \%$ confidence). The standard deviation of the negative missing $\mathrm{OH}$ reactivity data for each $1 \mathrm{~km}$ of altitude (left of the zero line) and of the positive missing $\mathrm{OH}$ reactivity data (right of the zero line) are shown at the $95 \%$ confidence level and indicate the skewness in the missing $\mathrm{OH}$ reactivity data distribution below $2-4 \mathrm{~km}$ altitude.

and a normal distribution. The standard normal quantiles are plotted on the $x$-axis and the sample quantiles on the $y$-axis. If the sample is perfectly normally distributed, then its values will lie along a straight line. Data lying higher than the line for values on the right side of the normal distribution (positive standard normal quantiles) indicate more high-value data than expected, while data higher than the line for values on the left side of the normal distribution (negative standard normal quantiles) indicate fewer low-value data than expected.

Q-Q plots are shown for three ATom 2 cases in Fig. 6. The large boxes are the interquartile range between the first quartile ( $25 \%$ of the data below it) and the third quartile $(75 \%$ below). The missing $\mathrm{OH}$ reactivity data for altitudes greater than $8 \mathrm{~km}$ (red data) are normally distributed until the standard normal quantile of 2, meaning that less than a few percent of the data is higher than expected. On the other hand, the missing $\mathrm{OH}$ reactivity data in the MBL (blue data) are normally distributed between standard normal quantiles of -2 and 1 , meaning that a few percent of low-value data is less than expected, but, more importantly, as much as $20 \%$ of the high-value data is greater than expected. Also included in Fig. 6 is the case for which we assume that the MBL missing $\mathrm{OH}$ reactivity zero value is actually greater by the missing $\mathrm{OH}$ reactivity absolute uncertainty at $95 \%$ confidence (gray data). Comparing these two MBL cases shows that changes in the mean missing $\mathrm{OH}$ reactivity values affect only the median value and not the distribution skewness. Q-Q plots for ATom1 and ATom2 (not shown) are less dramatic but still have the same characteristics: for measurements above $8 \mathrm{~km}$,

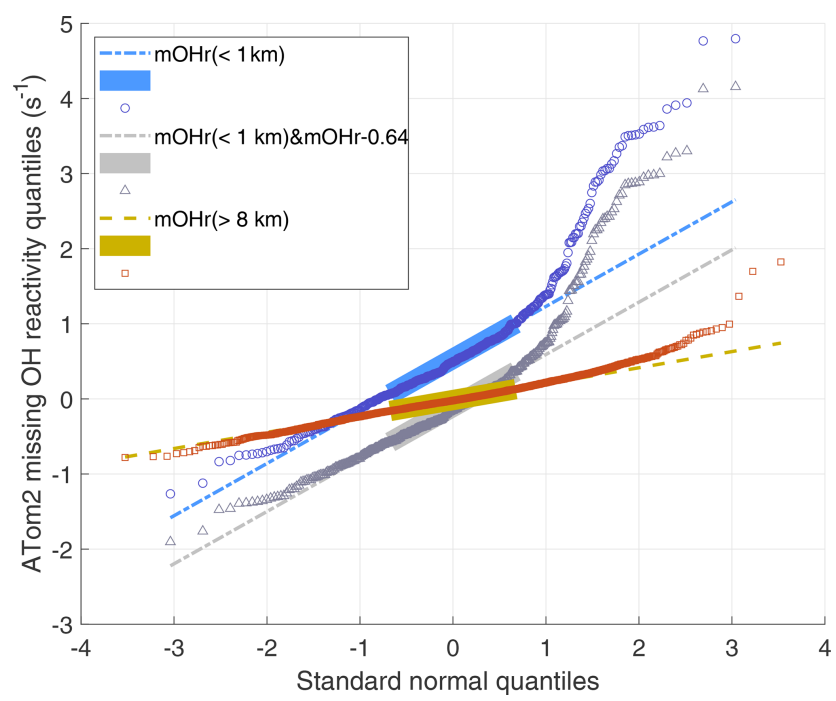

Figure 6. ATom 2 quantile-quantile plot for $1 \mathrm{~min}$ missing $\mathrm{OH}$ reactivity values above $8 \mathrm{~km}$ (red squares) and below $1 \mathrm{~km}$ (blue circles) versus a normal distribution with a mean of 0 and a standard deviation of 1 . The $\mathrm{Q}-\mathrm{Q}$ plot for data taken below $1 \mathrm{~km}$ but with the median value shifted by $0.64 \mathrm{~s}^{-1}$ (gray triangles) shows the effect of an incorrect absolute missing $\mathrm{OH}$ reactivity median. The values lie along the dashed lines if the missing $\mathrm{OH}$ reactivity values are normally distributed. This Q-Q plot is for ATom2; the Q-Q plots for ATom1 and ATom3 show less dramatic but similar behavior to that of ATom2.

the high-value data are more normally distributed; for measurement in the MBL, $\sim 20 \%$ of high-value data are greater than expected.

All of these statistical tests provide strong evidence for an abnormal amount of larger-than-expected missing $\mathrm{OH}$ reactivity in the MBL and up to $2-4 \mathrm{~km}$ altitude. It is possible that some individual outliers of the $1 \mathrm{~min}$ data are due to anomalous OHR instrument issues. The few outlier data points at higher altitude could be due to these instrument issues but may also be due to pollution plumes that were encountered. However, it seems highly unlikely that $\sim 20 \%$ of the higherthan-expected data at low altitudes could be caused by them. Thus, $\mathrm{OH}$ reactivity in the MBL is likely missing and needs to be further investigated.

\subsection{Global Missing $\mathrm{OH}$ reactivity in the marine boundary layer}

The frequent dips to below $200 \mathrm{~m}$ altitude gave $\sim 120$ opportunities to examine the global distribution of missing $\mathrm{OH}$ reactivity. The measured $\mathrm{OH}$ reactivity averaged for each dip (Fig. 7a, c, d) in the MBL (filled circles) is generally greater in the midlatitudes and tropics than in the higher latitudes, reaching as high as $4-5 \mathrm{~s}^{-1}$ over the Northern Hemisphere Pacific Ocean. More typical calculated values are $1.5 \pm 0.6 \mathrm{~s}^{-1}$, with relatively little variation. As a result, the 

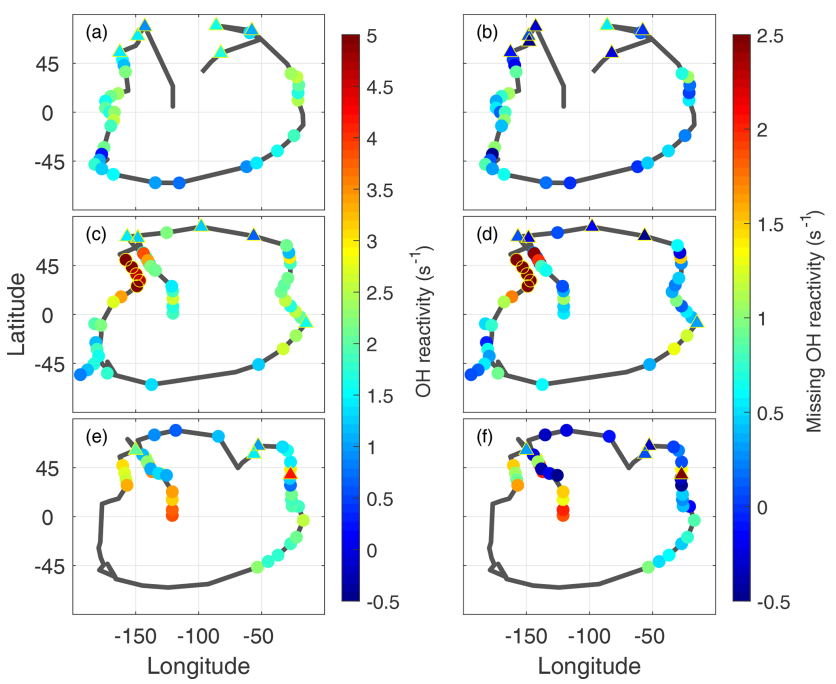

Figure 7. Global measured $\mathrm{OH}$ reactivity (a, c, e) and missing $\mathrm{OH}$ reactivity (b, d, f) for ATom1 (August), ATom2 (February), and ATom3 (October) at the per-dip time resolution. The black lines trace the flight path during each deployment, identical to the yellow tracks in Fig. 1. Color indicates the measured $\mathrm{OH}$ reactivity $(-0.5$ to $5 \mathrm{~s}^{-1}$ scale) and the missing $\mathrm{OH}$ reactivity $\left(-0.5\right.$ to $2.5 \mathrm{~s}^{-1}$ scale), while the yellow open circles indicate values in ATom 2 above $2 \mathrm{~s}^{-1}$ that were not included in the correlation analysis. Triangles outlined by yellow are overland values for both measured $\mathrm{OH}$ reactivity and missing $\mathrm{OH}$ reactivity.

missing $\mathrm{OH}$ reactivity values reflect the measured $\mathrm{OH}$ reactivity values.

Missing $\mathrm{OH}$ reactivity varied from $\sim 0$ to $\sim 2.5 \mathrm{~s}^{-1}$ (Fig. 7b, d, f). The lowest values occurred predominantly in the polar regions but also occasionally in the midlatitudes and tropics. High values exceeding $1 \mathrm{~s}^{-1}$ occurred predominantly over the Northern Hemisphere Pacific Ocean. The highest values occurred in ATom2, but values exceeding $2 \mathrm{~s}^{-1}$ were also observed in ATom3. Missing $\mathrm{OH}$ reactivity appears to vary in both place and time.

A plot of missing $\mathrm{OH}$ reactivity as a function of latitude shows these variations in place and time (Fig. 8). There is a general tendency for missing $\mathrm{OH}$ reactivity to be greatest over the midlatitudes and tropics and to decrease toward the poles. A sampling bias (Fig. 7) may be the reason for nearzero missing $\mathrm{OH}$ reactivity in the northern high latitudes and not in the southern high latitudes. However, the high missing $\mathrm{OH}$ reactivity over the Northern Hemisphere Pacific Ocean is exceptional.

A special note should be made regarding the North Pacific data for ATom2. One flight (Anchorage, Alaska, to KailuaKona, Hawai'i) accounts for missing $\mathrm{OH}$ reactivity values greater than $\sim 2.5 \mathrm{~s}^{-1}$. These points are anomalous in the context of all ATom $\mathrm{OH}$ reactivity measurements, and they do not correlate with the modeled influence from fires, convection, land, or the stratosphere. While present on all figures

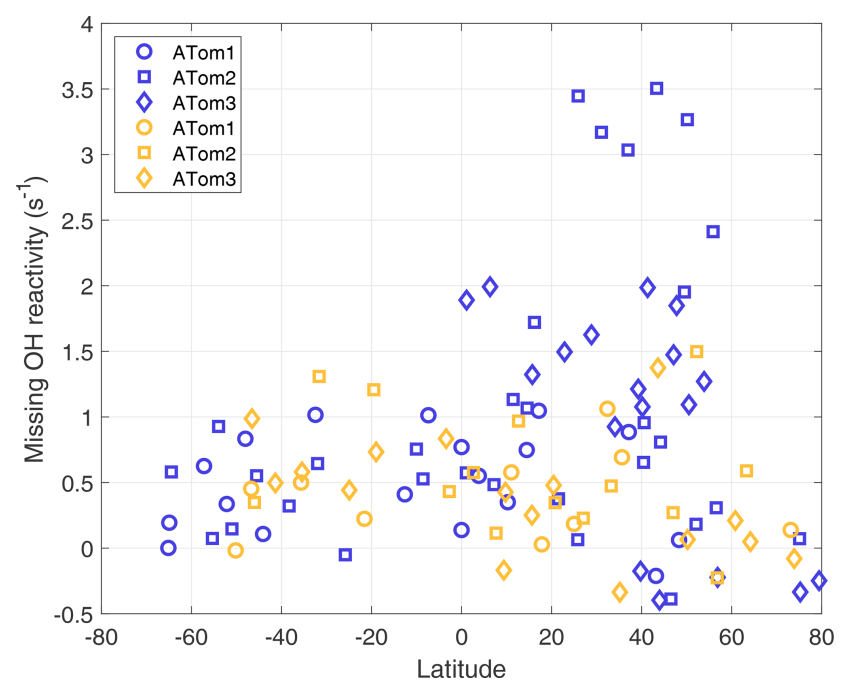

Figure 8. Missing OH reactivity averaged per-dip versus latitude over the Pacific Ocean (blue) and the Atlantic Ocean (gold).

except Fig. 8, they were not included in the correlation analysis described below.

\section{$3.4 \mathrm{OH}$ reactivity over land}

Of the approximately 120 dips in which $\mathrm{OH}$ reactivity measurements were made, $14 \%$ were over land (Fig. 7). The majority of these were made in the Arctic, with several being over snow, ice, and tundra. As a result, the mean calculated $\mathrm{OH}$ reactivity was only $1.35 \mathrm{~s}^{-1}$, while the mean measured $\mathrm{OH}$ reactivity was $1.4 \mathrm{~s}^{-1}$ and the mean missing $\mathrm{OH}$ reactivity was $-0.1 \mathrm{~s}^{-1}$, which is essentially zero to well within uncertainties. Note, however, that there is little missing $\mathrm{OH}$ reactivity over most of the Arctic polar oceans as well as over the Arctic land, which means that missing $\mathrm{OH}$ reactivity is generally low over the entire colder Arctic region. The greatest measured missing $\mathrm{OH}$ reactivity was found in only one dip in ATom3 over the Azores, where the missing $\mathrm{OH}$ reactivity was $\sim 2.5 \mathrm{~s}^{-1}$.

\subsection{Correlation of missing $\mathrm{OH}$ reactivity with other factors}

From the procedure given in Sect. 2.6, missing $\mathrm{OH}$ reactivity has the four strongest correlations with butanal $\left(\mathrm{C}_{3} \mathrm{H}_{7} \mathrm{CHO}\right)$, dimethyl sulfide (DMS, $\mathrm{CH}_{3} \mathrm{SCH}_{3}$ ), formaldehyde ( $\mathrm{HCHO}$ ), and SST, as shown in Fig. 9. Missing OH reactivity also correlates with some modeled pptv-level butanal products, but at these low levels these chemical species could not be the source of the missing $\mathrm{OH}$ reactivity. Interestingly, missing $\mathrm{OH}$ reactivity correlates only weakly with acetaldehyde and chlorophyll. These correlations suggest that the missing $\mathrm{OH}$ reactivity comes for an unknown VOC or OVOC that has $\mathrm{HCHO}$ and butanal as products and is co-emitted with DMS. The correlation with SST suggests an ocean source, as a 


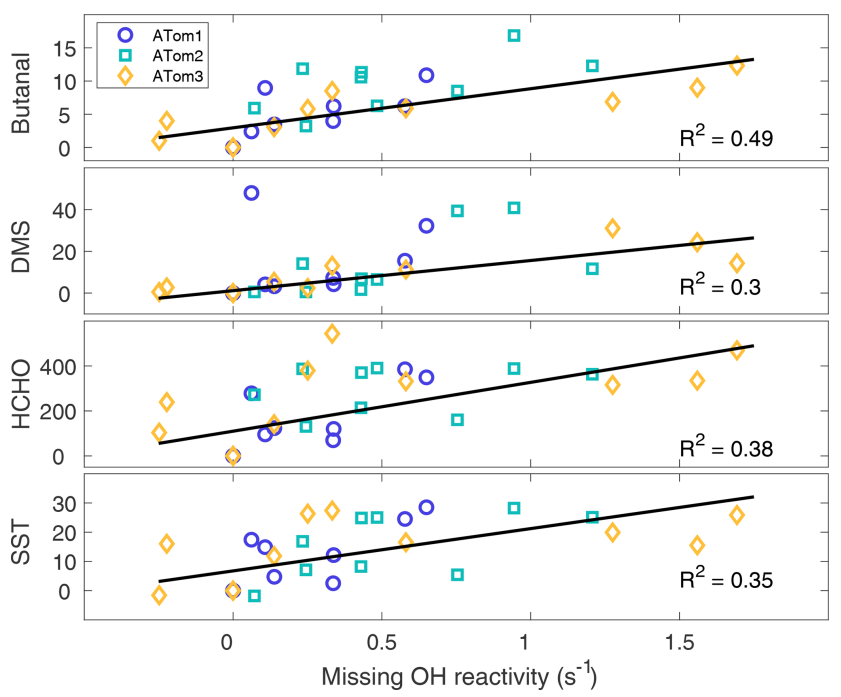

Figure 9. The best correlations with missing $\mathrm{OH}$ reactivity for data at the per-flight resolution across all latitudes and hemispheres. The symbols are per-flight data for ATom1 (circles), ATom2 (squares), and ATom3 (diamonds). Black lines are least-squares fits to the perflight data (units are ppbv for butanal and DMS, pptv for HCHO, and ${ }^{\circ} \mathrm{C}$ for SST).

higher temperature implies more emissions. Either biological activity of phytoplankton in the sea surface microlayer (Brooks and Thornton, 2017; Lana et al., 2011) or abiotic sea surface interfacial photochemistry (Brüggemann et al., 2018) could be the source of these VOCs and OVOCs.

\subsection{Comparison to INTEX-B}

$\mathrm{HCHO}$ is a good indicator of VOC photochemistry because it is an oxidation product for many VOCs. Thus, HCHO should correlate with missing $\mathrm{OH}$ reactivity. The ATom missing $\mathrm{OH}$ reactivity at the per-dip time resolution is compared to the Mao et al. (2009) missing $\mathrm{OH}$ reactivity below $2 \mathrm{~km}$ for times when NO is less than 100 pptv (Fig. 10). We use the per-dip time resolution of $\sim 5 \mathrm{~min}$ in this comparison rather than perflight time resolution to better align with the time resolution in Mao et al. (2009) of $3.5 \mathrm{~min}$. The anomalously high missing $\mathrm{OH}$ reactivity from ATom2 is not included in the data for the ATom linear fit. The INTEX-B correlation coefficient between missing $\mathrm{OH}$ reactivity and $\mathrm{HCHO}\left(R^{2}=0.58\right)$ is better than the one found for ATom $\left(R^{2}=0.35\right)$, but in the range of ATom HCHO (100-500 pptv) the ATom correlation coefficient is larger.

The linear fit of the missing $\mathrm{OH}$ reactivity against $\mathrm{HCHO}$ data from Mao et al. (2009) is given as the solid red line in Fig. 10. If instead the pressure-dependent offset is used for Mao et al. (2009), then the resulting missing $\mathrm{OH}$ reactivity against $\mathrm{HCHO}$ follows the dashed red line. With the absolute INTEX-B offset uncertainty at $\pm 0.5 \mathrm{~s}^{-1}$ and the absolute ATom offset uncertainty at $\pm 0.32 \mathrm{~s}^{-1}$, both at the

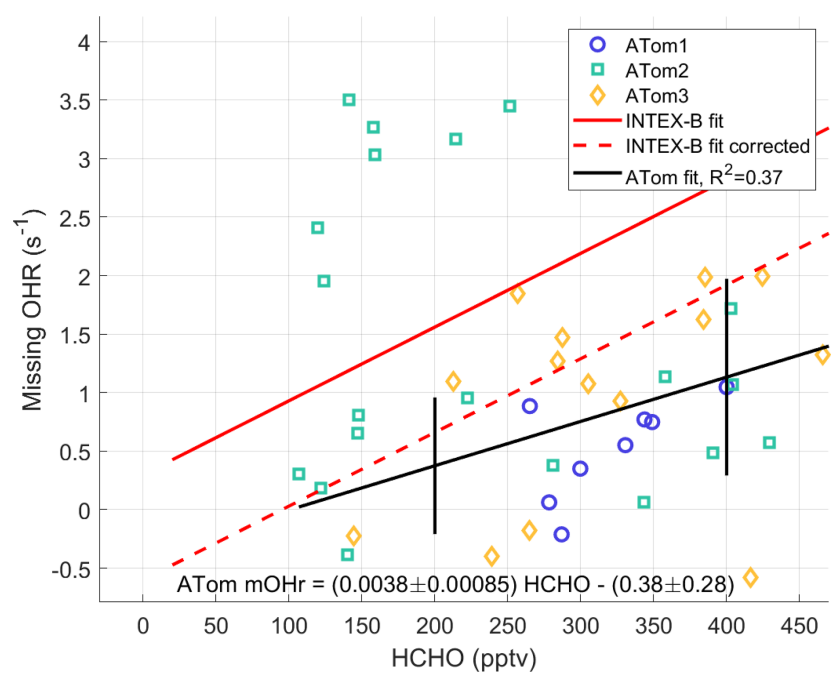

Figure 10. Missing $\mathrm{OH}$ reactivity against $\mathrm{HCHO}$ for per-dip values in the MBL over the Northern Hemisphere Pacific Ocean. The ATom linear fit (black line) is shown with values for ATom1 (circles), ATom2 (squares), and ATom3 (diamonds). The ATom linear fit is compared to the linear fit for missing $\mathrm{OH}$ reactivity values of Mao et al. (2009) (red line) and to this linear fit with an offset correction (red dashed line; see text). Uncertainty bars are the absolute uncertainty (95\% confidence) of the missing $\mathrm{OH}$ reactivity. The statistical uncertainty in the slope and intercept of the linear fit are given in the equation on the figure.

$68 \%$ confidence level, the linear fits for missing $\mathrm{OH}$ reactivity against $\mathrm{HCHO}$ in ATom and INTEX-B agree to within combined uncertainties. The ATom linear fit slope is only 2.7 standard deviations from the INTEX-B slope, but it is 4.4 standard deviations from a line with zero slope, making it highly unlikely that missing $\mathrm{OH}$ reactivity is not correlated with HCHO. The INTEX-B and ATom slopes to the linear fits are not exactly the same. However, given the uncertainties, the $\mathrm{HCHO}$ dependence of the adjusted missing $\mathrm{OH}$ reactivity found in INTEX-B is consistent with that found for the ATom missing $\mathrm{OH}$ reactivity over the North Pacific Ocean.

\section{Discussion}

Mao et al. (2009) calculated the $\mathrm{HO}_{2} / \mathrm{OH}$ ratio assuming that the cycling between $\mathrm{OH}$ and $\mathrm{HO}_{2}$ was much greater than $\mathrm{HO}_{x}$ production. That assumption is not valid for ATom because the low $\mathrm{NO}$ and $\mathrm{OH}$ reactivity values reduce the recycling to rates comparable to $\mathrm{HO}_{x}$ production (Brune et al., 2020). On the other hand, by adding simple $X$ photochemistry to the MCMv331 mechanism, as discussed in Sect. 2.5, it is possible to determine if the measured $\mathrm{OH}$ and $\mathrm{HO}_{2}$ are consistent with observed missing $\mathrm{OH}$ reactivity. For case one, in which there is no $\mathrm{OH}$ produced in the $\mathrm{X}$ oxidation sequence, the modeled $\mathrm{OH}$ and $\mathrm{HO}_{2}$ become $30-40 \%$ less than observed at altitudes below $2 \mathrm{~km}$. On the other hand, 
if $\mathrm{XO}_{2}$ and its products always autoxidize to produce $\mathrm{OH}$ (Crounse et al., 2013), then the modeled $\mathrm{OH}$ and $\mathrm{HO}_{2}$ become $10-20 \%$ greater than observed. The optimum agreement between observed and modeled $\mathrm{OH}$ and $\mathrm{HO}_{2}$ would require a partial recycling of $\mathrm{OH}$, but without knowing the identity of $\mathrm{X}$ it is not possible to know the fraction of $\mathrm{OH}$ that should be recycled in the chemical mechanism. Thus, this analysis neither supports nor refutes the missing $\mathrm{OH}$ reactivity measurements.

Several recent studies provide evidence for an unknown VOC or OVOC emitted into the atmosphere from the ocean. Oceanic sources have also been proposed for butanes and pentanes in some regions (Pozzer et al., 2010) and for methanol (Read et al., 2012). Measurements of biogenic VOCs in coastal waters found monoterpenes, C12-C15 nalkanes, and several higher aldehydes that could contribute to enhanced OH reactivity (Tokarek et al., 2019).

Unexpectedly large abundances of acetaldehyde $\left(\mathrm{CH}_{3} \mathrm{CHO}\right)$ have been observed in the marine boundary layer and the free troposphere (Singh et al., 2004; Millet et al., 2010; Read et al., 2012; Nicely et al., 2016; Wang et al., 2019), and the ocean is the suspected source. While earlier measurements may have been compromised with interferences, recent measurements of unexpectedly large acetaldehyde abundances are supported by unexpectedly large abundances of peroxyacetic acid, which is produced almost exclusively through acetaldehyde oxidation (Wang et al., 2019). Wang et al. observed that the ocean effects on acetaldehyde were confined primarily to the MBL and were able to approximately model the vertical distribution by using direct ocean emissions of acetaldehyde. However, it is possible that some of the observed acetaldehyde was produced by rapid oxidation of VOCs or OVOCs emitted from the ocean.

The missing $\mathrm{OH}$ reactivity is primarily in the MBL but often extends upward to as high as 2 to $4 \mathrm{~km}$ in some dips. Above $4 \mathrm{~km}$, the $\mathrm{OH}$ reactivity measurements are too near their LOD and thus too noisy to know if missing $\mathrm{OH}$ reactivity and acetaldehyde decrease the same way with altitude, but it is possible that they do. A similar decrease with altitude would imply that the unknown reactant lives long enough to be distributed throughout the free troposphere. If, on the other hand, the missing $\mathrm{OH}$ reactivity is only in and just above the MBL, then the unknown reactant could have a much shorter lifetime. The lack of correlation between missing $\mathrm{OH}$ reactivity and acetaldehyde in the MBL suggests that the unknown reactant responsible for the missing $\mathrm{OH}$ reactivity is not necessarily connected only to an ocean source of acetaldehyde.

From Eq. (5) and the measured missing $\mathrm{OH}$ reactivity, the abundance of the chemical species $\mathrm{X}$ would typically be a few tenths of a ppbv, assuming that $\mathrm{X}$ is a sesquiterpene with a typical reaction rate coefficient of $1 \times 10^{-10} \mathrm{~cm}^{3} \mathrm{~s}^{-1}$. The mean value for $X$ is $0.26 \pm 0.23 \mathrm{ppbv}$ for the per-dip bins. If $\mathrm{X}$ is an alkane with a typical reaction rate coefficient of $2.3 \times$
$10^{-12} \mathrm{~cm}^{3} \mathrm{~s}^{-1}$, then its mixing ratio will need to be more than 10 ppbv.

If the unknown VOC is an alkane with a reaction rate coefficient with $\mathrm{OH}$ of $2.3 \times 10^{-12} \mathrm{~cm}^{3} \mathrm{~s}^{-1}$, then an unlikely large oceanic source of $340 \mathrm{Tg} \mathrm{C} \mathrm{yr}^{-1}$ will be necessary (Travis et al., 2020). Adding this much additional VOC reduces global modeled $\mathrm{OH}$ by $20-50 \%$ along the ATom 1 flight tracks, degrading the reasonable agreement with measured $\mathrm{OH}$. However, if the VOC is an alkene for which $\mathrm{OH}$ is recycled in the reaction sequence, then modeled $\mathrm{OH}$ will probably remain in better agreement with measured $\mathrm{OH}$. Large sources of longlived unknown VOCs, which do not have as large an impact on modeled $\mathrm{OH}$, are also necessary to reduce but not resolve the discrepancies between measured and modeled acetaldehyde, especially in the Northern Hemisphere summer. These issues between a global model and measured missing $\mathrm{OH}$ reactivity and acetaldehyde need to be resolved.

\section{Conclusions}

Measured $\mathrm{OH}$ reactivity significantly exceeds calculated $\mathrm{OH}$ reactivity in the marine boundary layer during ATom. This missing $\mathrm{OH}$ is most prominent over the tropical and North Pacific Ocean, where it had mean values of $0.4-0.7 \mathrm{~s}^{-1}$ for the different ATom deployments, but rose to more than $2 \mathrm{~s}^{-1}$ at some locations. These higher values correspond to $\sim 0.26 \mathrm{ppbv}$ of a fast-reacting VOC, such as a sesquiterpene. The correlation of missing $\mathrm{OH}$ reactivity with formaldehyde, butanal, dimethyl sulfide, and sea surface temperature and the requirements for a smaller unknown reactive gas abundance and ocean source strength suggest that an ocean source of short-lived reactive gases, possibly VOCs or OVOCs, is responsible. This missing $\mathrm{OH}$ reactivity is qualitatively consistent with the observed unexpectedly large abundances of acetaldehyde, peroxyacetic acid, and other oxygenated VOCs. They may share the same cause. Finding this cause will require focused studies of detailed atmospheric composition in regions where missing $\mathrm{OH}$ reactivity and acetaldehyde excesses are greatest.

Data availability. The data and model used in this paper are publicly available: data: https://doi.org/10.3334/ORNLDAAC/1581 (Wofsy et al., 2018); model framework: https://github.com/airchem/ F0AM (last access: 12 July 2019); and MCMv331 chemical mechanism: http://mcm.leeds.ac.uk/MCM/ (Rickard et al., 1997).

Author contributions. ABT, DOM, and WHB made the $\mathrm{OH}, \mathrm{HO}_{2}$, and $\mathrm{OH}$ reactivity measurements; performed the model runs; analyzed the data; and wrote the manuscript. GMW provided support of the use of the F0AM model framework used for the model runs. WHB, DOM, ABT, HMA, DRB, TPB, RC, JDC, BCD, GSD, JPD, JWE, SRH, TFH, RAH, EH, MJK, KM, FLM, JMN, JP, TBR, JMS, 
CS, APT, CT, KU, POW, and GMW provided ATom measurements used for the modeling and reviewed and edited the manuscript.

Competing interests. The authors declare that they have no conflict of interest.

Acknowledgements. The authors thank the NASA ATom management team, pilots, logistical support team, aircraft operations team, and fellow scientists. We thank the reviewers for their helpful comments on the initial submission.

Financial support. This research has been supported by NASA (grant no. NNX15AG59A). This material is based upon work supported by the National Center for Atmospheric Research, which is a major facility sponsored by the National Science Foundation under cooperative agreement no. 1852977.

Review statement. This paper was edited by Andreas Hofzumahaus and reviewed by two anonymous referees.

\section{References}

Apel, E. C., Hornbrook, R. S., Hills, A. J., Blake, N. J., Barth, M. C., Weinheimer, A., Cantrell, C., Rutledge, S. A., Basarab, B., Crawford, J., Diskin, G., Homeyer, C. R., Campos, T., Flocke, F., Fried, A., Blake, D. R., Brune, W., Pollack, I., Peischl, J., Ryerson, T., Wennberg, P. O., Crounse, J. D., Wisthaler, A., Mikoviny, T., Huey, G., Heikes, B., O’Sullivan, D., and Riemer, D. D.: Upper tropospheric ozone production from lightning $\mathrm{NO}_{x}^{-}$impacted convection: Smoke ingestion case study from the DC3 campaign, J. Geophys. Res.-Atmos., 120, 2505-2523, https://doi.org/10.1002/2014JD022121, 2015.

Assaf, E., Sheps, L., Whalley, L., Heard, D., Tomas, A., Schoemaecker, C., and Fittschen, C.: The Reaction between $\mathrm{CH}_{3} \mathrm{O}_{2}$ and $\mathrm{OH}$ Radicals: Product Yields and Atmospheric Implications, Environ. Sci. Technol., 51, 2170-2177, https://doi.org/10.1021/acs.est.6b06265, 2017.

ATom: Measurements and modeling results from the NASA Atmospheric Tomography Mission, available at: https://espoarchive. nasa.gov/archive/browse/atom (last access: 9 August 2019), 2016.

Brooks S. D. and Thornton D. C. O.: Marine Aerosols and Clouds, Annu. Rev. Mar. Sci., 10, 289-313, https://doi.org/10.1146/annurev-marine-121916-063148, 2017.

Brüggemann, M. Hayeck, N., and George, C.: Interfacial photochemistry at the ocean surface is a global source of organic vapors and aerosols, Nat. Commun., 9, 3222, https://doi.org/10.1038/s41467-018-04528-7, 2018.

Brune, W. H., Miller, D. O., Thames, A. B., Allen, H. M., Apel, E. C., Blake, D. R., Bui, T. P., Commane, R., Crounse, J. D., Daube, B.C., Diskin, G. S., DiGangi, J. P., Elkins, J. W., Hall, S. R., Hanisco, T. F., Hannun, R. A., Hintsa, E. J., Hornbrook, R. S., Kim, M. J., McKain, K., Moore, F. L., Neuman,
J. A., Nicely, J. M., Peischl, J., Ryerson, T. B., St. Clair, J. M., Sweeney, C., Teng, A. P., Thompson, C., Ullmann, K., Veres, P. R., Wennberg, P. O., and Wolfe, G. M.: Exploring oxidation in the remote free troposphere: Insights from Atmospheric Tomography (ATom), J. Geophys. Res.-Atmos., 125, e2019JD031685, https://doi.org/10.1029/2019JD031685, 2020.

Burkholder, J. B., Sander, S. P., Abbatt, J., Barker, J. R., Huie, R. E., Kolb, C. E., Kurylo, M. J., Orkin, V. L., Wilmouth, D. M., and Wine, P. H.: Chemical Kinetics and Photochemical Data for Use in Atmospheric Studies, Evaluation No. 18, JPL Publication 15-10, Jet Propulsion Laboratory, Pasadena, available at: http: //jpldataeval.jpl.nasa.gov (last access: 13 November 2017), 2015.

Cazorla, M., Wolfe, G. M., Bailey, S. A., Swanson, A. K., Arkinson, H. L., and Hanisco, T. F.: A new airborne laser-induced fluorescence instrument for in situ detection of formaldehyde throughout the troposphere and lower stratosphere, Atmos. Meas. Tech., 8, 541-552, https://doi.org/10.5194/amt-8-541-2015, 2015.

Chan, K. R., Dean-Day, J., Bowen, S. W., and Bui, T. P.: Turbulence measurements by the DC- 8 meteorological measurement system, Geophys. Res. Lett., 25, 1355-1358, https://doi.org/10.1029/97GL03590, 1998.

Chen, H., Karion, A., Rella, C. W., Winderlich, J., Gerbig, C., Filges, A., Newberger, T., Sweeney, C., and Tans, P. P.: Accurate measurements of carbon monoxide in humid air using the cavity ring-down spectroscopy (CRDS) technique, Atmos. Meas. Tech., 6, 1031-1040, https://doi.org/10.5194/amt-6-1031-2013, 2013.

Colman, J. J., Swanson, A. L., Meinardi, S., Sive, B. C., Blake, D. R., and Rowland, F. S.: Description of the analysis of a wide range of volatile organic compounds in whole air samples collected during PEM-Tropics A and B, Anal. Chem., 73, 37233731, https://doi.org/10.1021/ac010027g, 2001.

Crounse, J. D., McKinney, K. A., Kwan, A. J., and Wennberg, P. O.: Measurement of gas-phase hydroperoxides by chemical ionization mass spectrometry, Anal. Chem., 78, 6726-6732, https://doi.org/10.1021/ac0604235, 2006.

Crounse, J. D., Nielsen, L. B., Jorgensen, S., Kjaergaard, H. G., and Wennberg, P. O.: Autoxidation of Organic Compounds in the Atmosphere, J. Phys. Chem. Lett., 4, 3513-3520, https://doi.org/10.1021/jz4019207, 2013.

Di Carlo, P., Brune, W. H., Martinez, M., Harder, H., Lesher, R., Ren, X. R., Thornberry, T., Carroll, M. A., Young, V., Shepson, P. B., Riemer, D., Apel, E., and Campbell, C.: Missing OH reactivity in a forest: Evidence for unknown reactive biogenic VOCs, Science, 304, 722-725, 2004.

Diskin, G. S., Podolske,J. R., Sachse, G. W., and Slate, T. A.: Open-path airborne tunable diode laser hygrometer, Proc. SPIE 4817, Diode Lasers and Applications in Atmospheric Sensing, https://doi.org/10.1117/12.453736, 2002.

Fuchs, H., Novelli, A., Rolletter, M., Hofzumahaus, A., Pfannerstill, E. Y., Kessel, S., Edtbauer, A., Williams, J., Michoud, V., Dusanter, S., Locoge, N., Zannoni, N., Gros, V., Truong, F., SardaEsteve, R., Cryer, D. R., Brumby, C. A., Whalley, L. K., Stone, D., Seakins, P. W., Heard, D. E., Schoemaecker, C., Blocquet, M., Coudert, S., Batut, S., Fittschen, C., Thames, A. B., Brune, W. H., Ernest, C., Harder, H., Muller, J. B. A., Elste, T., Kubistin, D., Andres, S., Bohn, B., Hohaus, T., Holland, F., Li, X., Rohrer, F., Kiendler-Scharr, A., Tillmann, R., Wegener, R., Yu, Z., Zou, Q., and Wahner, A.: Comparison of $\mathrm{OH}$ reactivity measurements in the atmospheric simulation chamber SAPHIR, At- 
mos. Meas. Tech., 10, 4023-4053, https://doi.org/10.5194/amt10-4023-2017, 2017.

Goldstein, A. H. and Galbally, I. E.: Known and Unexplored Organic Constituents in the Earth's Atmosphere, Environ, Sci. Technol., 41, 1514-1521, https://doi.org/10.1021/es072476p, 2007.

Jenkin, M. E., Saunders, S. M., and Pilling, M. J.: The tropospheric degradation of volatile organic compounds: a protocol for mechanism development, Atmos. Environ., 31, 81-104, https://doi.org/10.1016/S1352-2310(96)00105-7, 1997.

Jenkin, M. E., Saunders, S. M., Wagner, V., and Pilling, M. J.: Protocol for the development of the Master Chemical Mechanism, MCM v3 (Part B): tropospheric degradation of aromatic volatile organic compounds, Atmos. Chem. Phys., 3, 181-193, https://doi.org/10.5194/acp-3-181-2003, 2003.

Kaiser, J., Skog, K. M., Baumann, K., Bertman, S. B., Brown, S. B., Brune, W. H., Crounse, J. D., de Gouw, J. A., Edgerton, E. S., Feiner, P. A., Goldstein, A. H., Koss, A., Misztal, P. K., Nguyen, T. B., Olson, K. F., St. Clair, J. M., Teng, A. P., Toma, S., Wennberg, P. O., Wild, R. J., Zhang, L., and Keutsch, F. N.: Speciation of $\mathrm{OH}$ reactivity above the canopy of an isoprene-dominated forest, Atmos. Chem. Phys., 16, 93499359, https://doi.org/10.5194/acp-16-9349-2016, 2016.

Karion, A., Sweeney, C., Wolter, S., Newberger, T., Chen, H., Andrews, A., Kofler, J., Neff, D., and Tans, P.: Long-term greenhouse gas measurements from aircraft, Atmos. Meas. Tech., 6, 511-526, https://doi.org/10.5194/amt-6-511-2013, 2013.

Kovacs, T. A. and Brune, W. H.: Total OH loss rate measurement, J. Atmos. Chem., 39, 105-122, https://doi.org/10.1023/A:1010614113786, 2001.

Kovacs, T. A., Brune, W. H., Harder, H., Martinez, M., Simpas, J. B., Frost, G. J., Williams, E., Jobson, T., Stroud, C., Young, V., Fried, A., and Wert, B.: Direct measurements of urban $\mathrm{OH}$ reactivity during Nashville SOS in summer 1999, J. Environ. Monitor., 5, 68-74, 2003.

Lana, A., Bell, T. G., Simó, R., Vallina, S. M., Ballabrera-Poy, J., Kettle, A. J., Dachs, J., Bopp, L., Saltzman, E. S., Stefels, J., Johnson, J. E., and Liss, P. S.: An updated climatology of surface dimethylsulfide concentrations and fluxes in the global ocean, Global Biogeochem. Cy., 25, GB1004, https://doi.org/10.1029/2010GB003850, 2011.

Lambe, A. T., Ahern, A. T., Williams, L. R., Slowik, J. G., Wong, J. P. S., Abbatt, J. P. D., Brune, W. H., Ng, N. L., Wright, J. P., Croasdale, D. R., Worsnop, D. R., Davidovits, P., and Onasch, T. B.: Characterization of aerosol photooxidation flow reactors: heterogeneous oxidation, secondary organic aerosol formation and cloud condensation nuclei activity measurements, Atmos. Meas. Tech., 4, 445-461, https://doi.org/10.5194/amt-4445-2011, 2011.

Maasakkers, J. D., Jacob, D. J., Sulprizio, M. P., Scarpelli, T. R., Nesser, H., Sheng, J.-X., Zhang, Y., Hersher, M., Bloom, A. A., Bowman, K. W., Worden, J. R., Janssens-Maenhout, G., and Parker, R. J.: Global distribution of methane emissions, emission trends, and $\mathrm{OH}$ concentrations and trends inferred from an inversion of GOSAT satellite data for 2010-2015, Atmos. Chem. Phys., 19, 7859-7881, https://doi.org/10.5194/acp-197859-2019, 2019.

Mao, J., Ren, X., Brune, W. H., Olson, J. R., Crawford, J. H., Fried, A., Huey, L. G., Cohen, R. C., Heikes, B., Singh, H. B., Blake,
D. R., Sachse, G. W., Diskin, G. S., Hall, S. R., and Shetter, R. E.: Airborne measurement of OH reactivity during INTEX-B, Atmos. Chem. Phys., 9, 163-173, https://doi.org/10.5194/acp-9163-2009, 2009.

Millet, D. B., Guenther, A., Siegel, D. A., Nelson, N. B., Singh, H. B., de Gouw, J. A., Warneke, C., Williams, J., Eerdekens, G., Sinha, V., Karl, T., Flocke, F., Apel, E., Riemer, D. D., Palmer, P. I., and Barkley, M.: Global atmospheric budget of acetaldehyde: 3-D model analysis and constraints from in-situ and satellite observations, Atmos. Chem. Phys., 10, 3405-3425, https://doi.org/10.5194/acp-10-3405-2010, 2010.

Naik, V., Voulgarakis, A., Fiore, A. M., Horowitz, L. W., Lamarque, J.-F., Lin, M., Prather, M. J., Young, P. J., Bergmann, D., Cameron-Smith, P. J., Cionni, I., Collins, W. J., Dalsøren, S. B., Doherty, R., Eyring, V., Faluvegi, G., Folberth, G. A., Josse, B., Lee, Y. H., MacKenzie, I. A., Nagashima, T., van Noije, T. P. C., Plummer, D. A., Righi, M., Rumbold, S. T., Skeie, R., Shindell, D. T., Stevenson, D. S., Strode, S., Sudo, K., Szopa, S., and Zeng, G.: Preindustrial to present-day changes in tropospheric hydroxyl radical and methane lifetime from the Atmospheric Chemistry and Climate Model Intercomparison Project (ACCMIP), Atmos. Chem. Phys., 13, 5277-5298, https://doi.org/10.5194/acp13-5277-2013, 2013.

NASA Earth Observations: NASA EArth Observations, available at: https://neo.sci.gsfc.nasa.gov/, last access: 5 August 2019.

Nicely, J. M., Anderson, D. C., Canty, T. P., Salawitch, R. J., Wolfe, G. M., Apel, E.C., Arnold, S. R., Atlas, E. L., Blake, N. J., Bresch, J. F., Campos, T. L., Dickerson, R. R., Duncan, B., Emmons, L. K., Evans, M. J., Fernandez, R. P., Flemming, J., Hall, S. R., Hanisco, T. F., Honomich, S. B., Hornbrook, R. S., Huijnen, V., Kaser, L., Kinnison, D. E., Lamarque, J-F., Mao, J., Monks, S. A., Montzka, D. A., Pan, L. L., Riemer, D. D., SaizLopez, A., Steenrod, S. D., Stell, M. H., Tilmes, S., Turquety, S., Ullmann, K., and Weinheimer, A. J.: An observationally constrained evaluation of the oxidative capacity in the tropical western Pacific troposphere, J. Geophys. Res.-Atmos., 121, 74617488, https://doi.org/10.1002/2016JD025067, 2016.

Neuman, J. A., Trainer, M., Brown, S. S., Min, K.-E., Nowak, J. B., Parrish, D. D., and Veres, P. R.: HONO emission and production determined from airborne measurements over the Southeast U.S., J. Geophys. Res.-Atmos., 121, 9237-9250, https://doi.org/10.1002/2016JD025197, 2016.

Nölscher, A. C., Williams, J., Sinha, V., Custer, T., Song, W., Johnson, A. M., Axinte, R., Bozem, H., Fischer, H., Pouvesle, N., Phillips, G., Crowley, J. N., Rantala, P., Rinne, J., Kulmala, M., Gonzales, D., Valverde-Canossa, J., Vogel, A., Hoffmann, T., Ouwersloot, H. G., Vilà-Guerau de Arellano, J., and Lelieveld, J.: Summertime total $\mathrm{OH}$ reactivity measurements from boreal forest during HUMPPA-COPEC 2010, Atmos. Chem. Phys., 12, 8257-8270, https://doi.org/10.5194/acp-12-8257-2012, 2012.

Nölscher, A. C., Yañez-Serrano, A. M., Wolff, S., de Araujo, A. C., Lavrič, J. V., Kesselmeier, J., and Williams, J.: Unexpected seasonality in quantity and composition of Amazon rainforest air reactivity, Nat. Commun., 7, 10383, https://doi.org/10.1038/ncomms10383, 2016.

Pfannerstill, E. Y., Wang, N., Edtbauer, A., Bourtsoukidis, E., Crowley, J. N., Dienhart, D., Eger, P. G., Ernle, L., Fischer, H., Hottmann, B., Paris, J.-D., Stönner, C., Tadic, I., Walter, D., Lelieveld, J., and Williams, J.: Shipborne measurements of to- 
tal $\mathrm{OH}$ reactivity around the Arabian Peninsula and its role in ozone chemistry, Atmos. Chem. Phys., 19, 11501-11523, https://doi.org/10.5194/acp-19-11501-2019, 2019.

Pozzer, A., Pollmann, J., Taraborrelli, D., Jöckel, P., Helmig, D., Tans, P., Hueber, J., and Lelieveld, J.: Observed and simulated global distribution and budget of atmospheric $\mathrm{C}_{2}-\mathrm{C}_{5}$ alkanes, Atmos. Chem. Phys., 10, 4403-4422, https://doi.org/10.5194/acp10-4403-2010, 2010.

Prather, M. J., Holmes, C. D., and Hsu, J.: Reactive greenhouse gas scenarios: Systematic explorationof uncertainties and the role of atmospheric chemistry, Geophys. Res. Lett., 39, L09803, https://doi.org/10.1029/2012GL051440, 2012.

Read, K. A., Carpenter, L. J., Arnold, S. R., Beal, R., Nightingale, P. D., Hopkins, J. R., Lewis, A. C., Lee, J. D., Mendes, L., and Pickering, S. J.: Multiannual Observations of Acetone, Methanol, and Acetaldehyde in Remote Tropical Atlantic Air: Implications for Atmospheric OVOC Budgets and Oxidative Capacity, Environ. Sci. Technol., 46, 11028-11039, dx.doi.org/10.1021/es302082p, 2012.

Rickard, A., Young, J., Pilling, M., Jenkin, M., Pascoe, S., and Saunders, S.: The Master Chemical Mechanism, Version 3.3.1, available at: http://mcm.leeds.ac.uk/MCMv3.3.1/download.htt (last access: 12 July 2019), 1997.

Ryerson, T. B., Williams, E. J., and Fehsenfeld, F. C.: An efficient photolysis system for fast response $\mathrm{NO}_{2}$ measurements, J. Geophys. Res.-Atmos., 105, 26447-26461, https://doi.org/10.1029/2000JD900389, 2000.

Santoni, G. W., Daube, B. C., Kort, E. A., Jiménez, R., Park, S., Pittman, J. V., Gottlieb, E., Xiang, B., Zahniser, M. S., Nelson, D. D., McManus, J. B., Peischl, J., Ryerson, T. B., Holloway, J. S., Andrews, A. E., Sweeney, C., Hall, B., Hintsa, E. J., Moore, F. L., Elkins, J. W., Hurst, D. F., Stephens, B. B., Bent, J., and Wofsy, S. C.: Evaluation of the airborne quantum cascade laser spectrometer (QCLS) measurements of the carbon and greenhouse gas suite $-\mathrm{CO}_{2}, \mathrm{CH}_{4}, \mathrm{~N}_{2} \mathrm{O}$, and $\mathrm{CO}$ - during the CalNex and HIPPO campaigns, Atmos. Meas. Tech., 7, 1509-1526, https://doi.org/10.5194/amt-7-1509-2014, 2014.

Saunders, S. M., Jenkin, M. E., Derwent, R. G., and Pilling, M. J.: Protocol for the development of the Master Chemical Mechanism, MCM v3 (Part A): tropospheric degradation of nonaromatic volatile organic compounds, Atmos. Chem. Phys., 3, 161-180, https://doi.org/10.5194/acp-3-161-2003, 2003.

Shetter, R. E. and Mueller, M.: Photolysis frequency measurements using actinic flux spectroradiometry during the PEM-Tropics mission: Instrumentation description and some results, J. Geophys. Res.-Atmos., 104, 5647-5661, https://doi.org/10.1029/98JD01381, 1999.

Singh, H. B., Salas, L. J., Chatfield, R. B., Czech, E., Fried, A., Walega, J., Evans, M. J., Field, B. D., Jacob D. J., Blake, D., Heikes, B., Talbot, R., Sachse, G., Crawford, J. H., Avery, M. A., Sandholm, S., and Fuelberg, H.: Analysis of the atmospheric distribution, sources, and sinks of oxygenated volatile organic chemicals based on measurements over the Pacific during TRACE-P, J. Geophys. Res.-Atmos., 109, D15S07, https://doi.org/10.1029/2003JD003883, 2004.

Tokarek, T. W., Brownsey, D. K., Jordan, N., Garner, N. M., Ye, C. Z., and Osthoff, H. D.: Emissions of C9 - C16 hydrocarbons from kelp species on Vancouver Island: Alaria marginata (winged kelp) and Nereocystis luetkeana (bull kelp) as an at- mospheric source of limonene, Atmos. Environ., 2, 100007, https://doi.org/10.1016/j.aeaoa.2019.100007, 2019.

Travis, K. R., Heald, C. L., Allen, H. M., Apel, E. C., Arnold, S. R., Blake, D. R., Brune, W. H., Chen, X., Commane, R., Crounse, J. D., Daube, B. C., Diskin, G. S., Elkins, J. W., Evans, M. J., Hall, S. R., Hintsa, E. J., Hornbrook, R. S., Kasibhatla, P. S., Kim, M. J., Luo, G., McKain, K., Millet, D. B., Moore, F. L., Peischl, J., Ryerson, T. B., Sherwen, T., Thames, A. B., Ullmann, K., Wang, X., Wennberg, P. O., Wolfe, G. M., and Yu, F.: Constraining remote oxidation capacity with ATom observations, Atmos. Chem. Phys. Discuss., https://doi.org/10.5194/acp-2019-931, in review, 2020.

Jimenez, J. L., Campuzano-Jost, P., Nault, B. A., Crounse, J. D., Wennberg, P. O., Kim, M., Allen, H., Ryerson, T. B., Thompson, C. R., Peischl, J., Moore, F., Nance, D., Hall, B., Elkins, J., Tanner, D., Huey, L. G., Hall, S. R., Ullmann, K., Orlando, J. L., Tyndall, G. S., Flocke, F. M., Ray, E., Hanisco, T. F., Wolfe, G. M., St. Clair, J., Commane, R., Daube, B., Barletta, B., Blake, D. R., Weinzierl, B., Dollner, M., Conley, A., Vitt, F., Wofsy, S. C., Riemer, D. D., and Apel, E. C.: Atmospheric acetaldehyde: Importance of air-sea exchange and a missing source in the remote troposphere, Geophys. Res. Lett., 46, 5601-5613, https://doi.org/10.1029/2019GL082034, 2019.

Wofsy, S. C., Afshar, S., Allen, H. M., Apel, E., Asher, E. C., Barletta, B., Bent, J., Bian, H., Biggs, B. C., Blake, D. R., Blake, N., Bourgeois, I., Brock, C. A., Brune, W. H., Budney, J. W., Bui, T. P., Butler, A., Campuzano-Jost, P., Chang, C. S., Chin, M., Commane, R., Correa, G., Crounse, J. D., Cullis, P. D., Daube, B. C., Day, D. A., Dean-Day, J. M., Dibb, J. E., DiGangi, J. P., Diskin, G. S., Dollner, M., Elkins, J. W., Erdesz, F., Fiore, A. M., Flynn, C. M., Froyd, K., Gesler, D. W., Hall, S. R., Hanisco, T. F., Hannun, R. A., Hills, A. J., Hintsa, E. J., Hoffman, A., Hornbrook, R. S., Huey, L. G., Hughes, S., Jimenez, J. L., Johnson, B. J., Katich, J. M., Keeling, R. F., Kim, M. J., Kupc, A., Lait, L. R., Lamarque, J.-F., Liu, J., McKain, K., Mclaughlin, R. J., Meinardi, S., Miller, D. O., Montzka, S. A., Moore, F. L., Morgan, E. J., Murphy, D. M., Murray, L. T., Nault, B. A., Neuman, J. A., Newman, P. A., Nicely, J. M., Pan, X., Paplawsky, W., Peischl, J., Prather, M. J., Price, D. J., Ray, E., Reeves, J. M., Richardson, M., Rollins, A. W., Rosenlof, K. H., Ryerson, T. B., Scheuer, E., Schill, G. P., Schroder, J. C., Schwarz, J. P., St.Clair, J. M., Steenrod, S. D., Stephens, B. B., Strode, S. A., Sweeney, C., Tanner, D., Teng, A. P., Thames, A. B., Thompson, C. R., Ullmann, K., Veres, P. R., Vieznor, N., Wagner, N. L., Watt, A., Weber, R., Weinzierl, B., Wennberg, P., Williamson, C. J., Wilson, J. C., Wolfe, G. M., Woods, C. T., and Zeng, L. H.: ATom: Merged Atmospheric Chemistry, Trace Gases, and Aerosols, ORNL DAAC, Oak Ridge, Tennessee, USA, https://doi.org/10.3334/ORNLDAAC/1581, 2018.

Wolfe, G. M., Marvin, M. R., Roberts, S. J., Travis, K. R., and Liao, J.: The Framework for 0-D Atmospheric Modeling (F0AM) v3.1, Geosci. Model Dev., 9, 3309-3319, https://doi.org/10.5194/gmd9-3309-2016, 2016.

Yang, Y, Shao, M., Wang, X., Noelscher, A.C., Kessel, S., Guenther, A., and Williams, J.: Towards a quantitative understanding of total OH reactivity: A review, Atmos. Environ., 143, 147-161, 2016. 
Zannoni, N., Gros, V., Lanza, M., Sarda, R., Bonsang, B., Kalogridis, C., Preunkert, S., Legrand, M., Jambert, C., Boissard, C., and Lathiere, J.: $\mathrm{OH}$ reactivity and concentrations of biogenic volatile organic compounds in a Mediterranean forest of downy oak trees, Atmos. Chem. Phys., 16, 1619-1636, https://doi.org/10.5194/acp-16-1619-2016, 2016. 